First-line tandem high-dose chemotherapy and autologous stem cell transplantation versus single high-dose chemotherapy and autologous stem cell transplantation in multiple myeloma, a systematic review of controlled studies (Review)

Naumann-Winter F, Greb A, Borchmann P, Bohlius J, Engert A, Schnell R
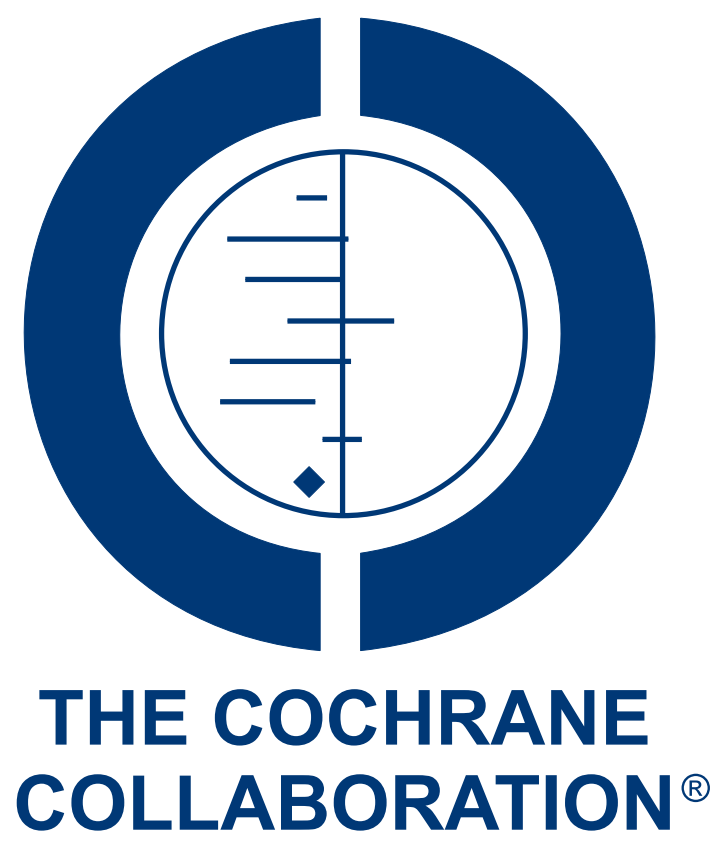

This is a reprint of a Cochrane review, prepared and maintained by The Cochrane Collaboration and published in The Cochrane Library 2012, Issue 10

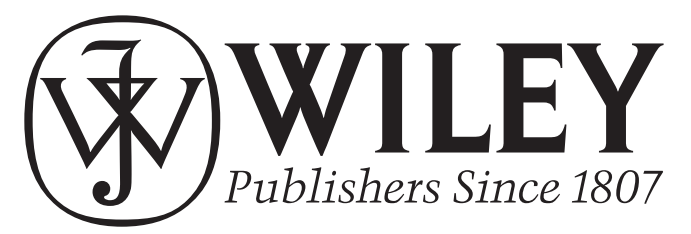

First-line tandem high-dose chemotherapy and autologous stem cell transplantation versus single high-dose chemotherapy and autologous stem cell transplantation in multiple myeloma, a systematic review of controlled studies (Review) Copyright $\odot 2012$ The Cochrane Collaboration. Published by John Wiley \& Sons, Ltd. 
TABLE OF CONTENTS

HEADER . . . . . . . . . . . . . . . . . . . . . . . . . . . . . . . . . . . . . . . 1

ABSTRACT . . . . . . . . . . . . . . . . . . . . . . . . . . . . . . . . . . . . . . 1

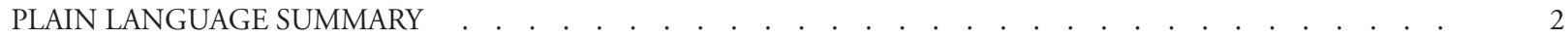

BACKGROUND . . . . . . . . . . . . . . . . . . . . . . . . . . . . . . . . . . . . 3

OBJECTIVES . . . . . . . . . . . . . . . . . . . . . . . . . . . . . . . . . . . . . . . . . . . 4

METHODS . . . . . . . . . . . . . . . . . . . . . . . . . . . . . . . . . . 4

Figure 1. . . . . . . . . . . . . . . . . . . . . . . . . . . . . . . . . . . . . . 7

Figure 2. . . . . . . . . . . . . . . . . . . . . . . . . . . . . . . . . . . . . . 9

RESULTS . . . . . . . . . . . . . . . . . . . . . . . . . . . . . . . . . . . . . . . 10

DISCUSSION . . . . . . . . . . . . . . . . . . . . . . . . . . . . . . . . . . . . . 14

AUTHORS' CONCLUSIONS . . . . . . . . . . . . . . . . . . . . . . . . . . . . . . . . . . . 17

ACKNOWLEDGEMENTS . . . . . . . . . . . . . . . . . . . . . . . . . . . . . . . . 18

REFERENCES . . . . . . . . . . . . . . . . . . . . . . . . . . . . . . . . . . . . . 18

CHARACTERISTICS OF STUDIES . . . . . . . . . . . . . . . . . . . . . . . . . . . . . . . . . . . . . 25

DATA AND ANALYSES . . . . . . . . . . . . . . . . . . . . . . . . . . . . . . . . . . . . . . . . . . . . . .

ADDITIONAL TABLES . . . . . . . . . . . . . . . . . . . . . . . . . . . . . . . . . . . . . . . 33

APPENDICES . . . . . . . . . . . . . . . . . . . . . . . . . . . . . . . . . . . . . . 43

HISTORY . . . . . . . . . . . . . . . . . . . . . . . . . . . . . . . . . . . . . . . 44

CONTRIBUTIONS OF AUTHORS . . . . . . . . . . . . . . . . . . . . . . . . . . . . . . . . . . . . . . . 44

DECLARATIONS OF INTEREST . . . . . . . . . . . . . . . . . . . . . . . . . . . . . . . . . . . 45

SOURCES OF SUPPORT . . . . . . . . . . . . . . . . . . . . . . . . . . . . . . . . . . . . . . . . . . 45

DIFFERENCES BETWEEN PROTOCOL AND REVIEW . . . . . . . . . . . . . . . . . . . . . . . . . 45

NOTES . . . . . . . . . . . . . . . . . . . . . . . . . . . . . . . . . . . . 45

First-line tandem high-dose chemotherapy and autologous stem cell transplantation versus single high-dose chemotherapy and autologous stem cell transplantation in multiple myeloma, a systematic review of controlled studies (Review) Copyright $\odot 2012$ The Cochrane Collaboration. Published by John Wiley \& Sons, Ltd. 


\title{
First-line tandem high-dose chemotherapy and autologous stem cell transplantation versus single high-dose chemotherapy and autologous stem cell transplantation in multiple myeloma, a systematic review of controlled studies
}

\author{
Frauke Naumann-Winter ${ }^{1,2}$, Alexander Greb ${ }^{2}$, Peter Borchmann ${ }^{3}$, Julia Bohlius ${ }^{4}$, Andreas Engert ${ }^{2,3}$, Roland Schnell ${ }^{2,3}$ \\ ${ }^{1}$ Federal Institute for Drugs and Medical Devices (BfArM), Bonn, Germany. ${ }^{2}$ Cochrane Haematological Malignancies Group, De- \\ partment I of Internal Medicine, University Hospital of Cologne, Cologne, Germany. ${ }^{3}$ Department I of Internal Medicine, University \\ Hospital of Cologne, Cologne, Germany. ${ }^{4}$ Institute of Social and Preventive Medicine, University of Bern, Bern, Switzerland \\ Contact address: Frauke Naumann-Winter, frauke.naumann@gmx.de. frauke.naumann@bfarm.de.
}

Editorial group: Cochrane Haematological Malignancies Group.

Publication status and date: New, published in Issue 10, 2012.

Review content assessed as up-to-date: 13 November 2011.

Citation: Naumann-Winter F, Greb A, Borchmann P, Bohlius J, Engert A, Schnell R. First-line tandem high-dose chemotherapy and autologous stem cell transplantation versus single high-dose chemotherapy and autologous stem cell transplantation in multiple myeloma, a systematic review of controlled studies. Cochrane Database of Systematic Reviews 2012, Issue 10. Art. No.: CD004626. DOI: 10.1002/14651858.CD004626.pub3.

Copyright (c) 2012 The Cochrane Collaboration. Published by John Wiley \& Sons, Ltd.

\begin{abstract}
A B S T R A C T
Background

Several clinical studies have compared single with tandem (also called double) autologous stem cell transplantation (ASCT) as first-line treatment in patients with symptomatic multiple myeloma (MM), one of the leading indications for ASCT worldwide.

Objectives

The present Cochrane Review compares tandem autologous stem cell transplantation (TASCT) with single autologous stem cell transplantation (SASCT) as first-line treatment in patients with symptomatic MM with respect to overall survival (OS), event-free survival (EFS), quality of life (QoL) and treatment- or transplantation-related mortality.
\end{abstract}

Search methods

We systematically identified controlled trials published between January 1995 and May 2011 in two bibliographic databases (MEDLINE and CENTRAL) and in clinical trial registries.

Selection criteria

One researcher screened references for controlled trials to determine eligibility for the systematic review (SR) according to pre-specified inclusion and exclusion criteria, reflecting characteristics of disease and the interventions. We required a minimal set of details to be reported for observational studies for the studies to be included.

Data collection and analysis

We critically evaluated eligible trials with respect to quality of design and actual performance. One researcher extracted individual trial results, which were checked by another researcher. We recapitulated the results of the individual trials in a standardised way for the SR in order to allow a systematic assessment of potential sources of bias.

First-line tandem high-dose chemotherapy and autologous stem cell transplantation versus single high-dose chemotherapy and I autologous stem cell transplantation in multiple myeloma, a systematic review of controlled studies (Review)

Copyright (๑) 2012 The Cochrane Collaboration. Published by John Wiley \& Sons, Ltd. 


\section{Main results}

Overall, we identified 14 controlled studies. One registered randomised controlled trial (RCT) is still recruiting patients at the time of this review and no clinical results have been published. Two registered RCTs have remained unpublished despite their termination. Publications on one RCT had been retracted. We excluded five observational studies since neither patients nor treatment regimens were sufficiently characterised to allow an assessment of potential confounding by indication. We conducted a SR of study designs, definition of endpoints, treatment regimens and baseline characteristics of patients in the five included RCTs (two full-text publications, three conference presentations) enrolling1506 patients in total. Because we identified substantial clinical and methodological heterogeneity, we refrained from conducting a formal meta-analysis.

While we included only previously untreated, symptomatic patients with MM the treatment regimens differed notably with respect to acute toxicity, between trials and also between study arms. Compared to state of the art treatment standards, the treatment regimens applied in all trials have to be considered as below standard from a contemporary perspective in at least one component.

Three trials were likely to have the potential of being highly biased while two RCTs had a moderate potential for bias. The observed treatment effects in the set of included trials may have been influenced by a steep decrease in compliance with the second ASCT and the concomitant selection of patients. In addition, OS data were confounded by the treatment subsequent to first-line therapy.

OS was statistically significantly improved in one trial only. While EFS was prolonged in four of the five trials, the median prolongation ranged between three to 12 months, with an uncertain direction of bias in the individual trials. QoL was not reported in any study. Results concerning treatment- or transplantation-related mortality could not be adequately assessed due to substantial differences in definitions between trials and low reporting quality.

\section{Authors' conclusions}

We did not consider any study to be sufficiently informative for contemporary treatment decisions concerning the question single versus tandem ASCT in view of inherent biases. In addition, none of the trials integrated the so-called "novel agents" which are now considered standard treatment for MM. To improve the quality of future studies, sample size calculations should consider the potentially steep decrease in compliance with the second ASCT. Reporting of results of treatment- or transplantation-related mortality should clearly specify the type and number of events (the numerator) in a well-defined population (the denominator).

\section{PLAIN LANGUAGE SUMMARY}

\section{High-dose chemotherapy plus single vs tandem autologous transplantation as initial treatment for multiple myeloma}

Multiple myeloma is a cancer of antibody-producing cells in the bone marrow. It causes bone destruction and patients are usually at a higher risk for infections and renal damage. Autologous stem cell transplantation has been established as standard initial treatment for fit patients with symptomatic multiple myeloma. During autologous stem cell transplantation, blood-forming stem cells are removed from the patient prior to intense chemotherapy and later given back to the same patient. The chemotherapy is aimed at killing tumour cells (the higher the dose the more tumour cells are killed) but also affects normal blood-forming cells that are needed to fight infections, transport oxygen and control bleeding. By giving the patient back his or her own blood-forming cells, the recovery from the chemotherapy is notably faster and better. Since it is unclear whether autologous stem cell transplantation as initial treatment of multiple myeloma should be performed once or twice, we systematically searched for publications addressing the question whether the acute toxicity of autologous stem cell transplantation is counterbalanced by a long-term benefit for the patient. Several studies in which patients undergoing one treatment with autologous stem cell transplantation were compared to patients undergoing autologous stem cell transplantation twice were identified. Only five of 14 studies identified could be analysed in the present systematic review. We were interested in long-term benefit for patients with respect to overall survival or so called event-free survival, that is survival without disease progression. Quality of life and treatment-related mortality should also be analysed in clinical studies.

When the included studies were analysed with respect to treatment regimen and design characteristics, all turned out to have methodological problems which do not allow us to draw firm conclusion from the findings. Since the way to treat multiple myeloma has changed since the performance of the included trials, conclusions cannot be drawn with respect to contemporary treatment decisions. We also noted that reporting of completed trials needs to be improved.

First-line tandem high-dose chemotherapy and autologous stem cell transplantation versus single high-dose chemotherapy and 


\section{B A C K G R O U N D}

\section{Description of the condition}

Multiple myeloma (MM) is a haematological malignancy that contributes to approximately $15 \%$ of haematological malignancies and close to $27 \%$ of all haematopoietic cell cancer-related deaths (Munshi 2008). The incidence increases steadily with age and 75\% of patients are older than 60 years (Durie 2001; Alexander 2007). Myeloma cells derive from antibody-producing B-cells, therefore $\mathrm{MM}$ is characterised by the presence of often non-functional monoclonal immunoglobulins in the serum or urine, or both (Laubach 2011). Patients frequently present with bone pain or increased susceptibility to infections, or both. Among other factors, the release of calcium from bone into the blood stream leads to hypercalcaemia; and the generally high protein concentration in serum may result in renal failure. End-organ damage is the decisive factor that indicates the necessity of starting aggressive treatment and it has a major impact on the quality of life (Anderson 2008).

Over decades, MM has been classified according to the DurieSalmon (DS) staging system which aims at correlating clinical features with an estimate of myeloma cell mass (Durie 1975). Recently, a new international staging system (ISS) based solely on two readily available laboratory tests ( $\beta 2$-microglobulin and albumin) has been developed (Greipp 2005).

Despite progress in the understanding of MM, especially regarding pathophysiology, its main causes remain unknown (Durie 2001; Alexander 2007). There seems to be more than one genetic pathway to MM and in addition to translocations, karyotypic instabilities are often observed. Hyperdiploid or non-hyperdiploid tumours carry different numbers of chromosomes and the two classes differ with respect to chromosomal content, stromal dependency and aggressiveness of the tumours (Fonseca 2009).

The clinical course of MM is very heterogeneous with overall survival (OS) ranging from months to decades depending on the stage of disease or the presence of prognostic factors for example (Gertz 2007). Of unfavourable prognosis are an especially bad performance status, older age, high plasma cell labelling index, and high $\beta 2$-microglobulin or lactate dehydrogenase levels (Fonseca 2007). More recently, cytogenetic changes such as chromosome 13 and chromosome 11 abnormalities are also proposed to have a strong correlation with a worse outcome (Fonseca 2009; Nahi 2011). The high frequency of patients who either are or become refractory to treatment, a feature also markedly impacting on treatment outcome, is thought to be related to the strong interactions between tumour cells and the surrounding stroma (Podar 2009).

Patients with stage I, II, and III disease according to the ISS have a median OS of 62, 44 and 29 months, respectively (Greipp 2005). An improvement of OS was demonstrated in the last decade, both in the relapsed setting as well as from diagnosis, with a doubling in OS for patients who were treated with one or more of the novel agents (thalidomide, lenalidomide or bortezomib) (Kumar 2008; Johnsen 2010; Turesson 2010).
Therapeutic strategies in MM not only focus on prolonging OS but also to induce tumour response, inhibit tumour progression and delay disease-related complications (Anderson 2008, Durie 2010). The surrogacy of tumour response with survival is still under discussion, however (Durie 2008; Harousseau 2009; Durie 2010). Validation of response as a patient-relevant outcome is mainly hampered by the dynamic changes in treatment from the high-dose combination chemotherapy approaches of the 1990s to integration of novel agents (Durie 2010).

One treatment approach for symptomatic MM was to intensify chemotherapy, either by increasing doses or by using combinations of multiple drugs (reviewed in Hahn 2003). The first highdose chemotherapy schemes resulted in high toxicity and extensive myelosuppression without substantial prolongation of survival (Barlogie 1986; Myeloma Trialists 98). Outcomes after intensive treatment were improved only by autologous stem cell transplantation (ASCT).

\section{Description of the intervention}

Eligibility for transplantation remains one of the main determinants of the treatment strategy until today (for example Kortüm 2010; NCCN 2011). A number of randomised trials have been performed comparing high-dose chemotherapy supported by ASCT with conventional chemotherapy as first-line treatment (cited in Levy 2005; Koreth 2007). The subsequent meta-analyses did not provide evidence for an extended OS after ASCT, but progression-free survival (PFS) was significantly improved ( Levy 2005; Koreth 2007). Importantly, the size and treatment effects with respect to both OS and PFS of single autologous stem cell transplantation (SASCT) over combination chemotherapy were quite variable in the individual trials (indeterminate, favourable and even unfavourable in one trial). Accordingly, the meta-analytical result indicated statistically significant heterogeneity (Levy 2005; Koreth 2007). Although transplantation-related mortality could be reduced to less than $5 \%$ in the majority of ASCT trials, it remained consistently higher after a transplantation regimen compared to chemotherapy alone, both in RCTs as well as in daily practice (Jantunen 2006a; Gertz 2008; Jones 2008).

\section{How the intervention might work}

Assuming a favourable outcome of SASCT compared to chemotherapy, in the early 1990s some investigators concentrated on tandem autologous stem cell transplantation (TASCT) (Harousseau 1992; Barlogie 1997). TASCT corresponds to a second prospectively planned ASCT within a few months after the first ASCT. TASCT was introduced to further improve or consolidate disease control as achieved after SASCT in view of a documented dose-response relationship of melphalan with improved outcome (Awedan 2002; Giralt 2010). 


\section{Why it is important to do this review}

MM is among the leading indications for ASCT in Europe and the USA (Copelan 2006; Gratwohl 2007). Two randomised studies comparing TASCT with SASCT as initial treatment in patients with symptomatic MM have been published as full text publications (IFM94; Bologna96). Further results from RCTs were presented at conferences (DSMM-I; GMMG-HD2; MAG95). As with RCTs comparing SASCT with combination chemotherapy (see Levy 2005; Koreth 2007), a statistically significant improvement of either survival endpoint was not consistently replicated in the other trials addressing the same question. This is a classical starting point for a meta-analysis aiming at determining clinical or methodical reasons for the observed heterogeneity, either with respect to statistical significance or with respect to the size of the treatment effect (Egger 2001; Higgins 2011; Pignon 2001).

Although TASCT has been used as first-line treatment of MM for more than 16 years now, there is continued controversy about its value. There is concern that the increased short-term risks associated with double intensified treatment might call into question the benefit of long-term disease control, in all or specific subgroups of patients (Fermand 2007; Barlogie 2007; Tricot 2008). Thus, an 'acceptable level of toxicity' for the primary MM treatment is still unclear. Usually, higher toxicity is accepted for a curative treatment compared to a palliative treatment (EMA/CHMP/EWP/520088/2008).

On the one hand, TASCT is an integral component of a "Total Therapy" programme (TT), which currently includes novel agents in both the induction and maintenance treatment regimen (Barlogie 1997; Total therapy). Barlogie and colleagues support TT as a key to the cure of MM (Barlogie 2009). Some investigators, however, have started to regard MM as a chronic disease and principally question the value of an intensive (and thereby toxic) treatment approach (Rajkumar 2008; Attal 2009; Gertz 2009).

\section{O B J E C T I VES}

We systematically reviewed the evidence on the effects of TASCT compared to SASCT as first-line treatment in MM on overall survival (OS), event-free survival (EFS) and treatment- or transplantation-related mortality. By systematically reviewing both prospectively planned features of the included trials and actual experiences recorded during their performance, we aimed to contribute to a discussion on clinical and methodological issues critical for the interpretation of the available evidence.

\section{METHODS}

\section{Criteria for considering studies for this review}

\section{Types of studies}

Both randomised and non-randomised trials comparing first-line TASCT with SASCT in patients with symptomatic MM were included into the systematic review according to pre-specified inclusion and exclusion criteria (Table 1). All of the inclusion criteria had to be fulfilled and none of the exclusion criteria for including a study. Duration of follow-up was not a criterion for selecting trials.

The reason for including comparative observational studies in the search for the systematic review was to prepare for customary reproaches against RCTs, that is their alleged artificiality or distance from clinical practice. In order for observational studies to be included, however, they had to report on a contemporary control group and both groups needed to be described with sufficient detail to allow assessment of potential 'confounding by indication' (Kunz 1998; Klungel 2004; Klein-Geltink 2007; Vandenbroucke 2008). At least baseline characteristics, the treatment regimen and outcome data for the two groups had to be reported separately for both groups.

In view of a potentially critical publication bias if only full-text articles were accepted, conference presentations of RCTs were eligible (Krzyzanowska 2003; Curt 2008; Ramsey 2008; Tam 2008) while full-text publications only were acceptable for observational studies.

\section{Types of participants}

We included patients with MM at first diagnosis. Prior treatment was accepted if patients had been treated conventionally (melphalan, prednisone) for a limited time span (up to six months) (see Differences between protocol and review). No age restriction was applied.

We excluded patients with a localised form of myeloma as it has different biological behaviour and requires different treatment. We also excluded studies in patients with preliminary stages of $\mathrm{MM}$ and the closely related monoclonal gammopathy of unknown significance as well as smoldering myeloma, for which treatment is not recommended.

\section{Types of interventions}

We included all studies comparing first-line TASCT with SASCT. We included all trials assessing TASCT regardless of the timing of transplantation as long as the second transplantation was prospectively planned as first-line treatment, before disease progression. We accepted all types of induction, conditioning and maintenance regimens and included studies irrespective of the source of stem cells.

\section{Types of outcome measures}

Ideally, both prolongation of the objective endpoint OS and improved quality of life should be used for demonstrating patient

First-line tandem high-dose chemotherapy and autologous stem cell transplantation versus single high-dose chemotherapy and 
benefit (Anderson 2008; Durie 2010). Quality of life measures were, however, only to be included if they were assessed by validated instruments. Considerable confounding of OS was expected in all included RCTs as all were performed in the years during which the so-called 'novel agents', with considerable efficacy in MM (thalidomide, lenalidomide or bortezomib), were developed for MM (Kumar 2008). Therefore, EFS can be considered as an indicator of efficacy as long as a deleterious effect on OS could be excluded, in an analogy to drug development (CPMP/EWP/205/95 2005). It is important to note that EFS also includes laboratory parameters which signal progression but need not immediately affect the patients' health status. Since the criteria for progression became more sophisticated over the time period during which the included trials were performed, for example by increasing sensitivity with respect to progression using immunofixation, there is some heterogeneity of definitions used in all included trials (Attal 1996,; Bladé 1998; Durie 2006). The outcome in clinical trials in oncology is often also assessed by measuring response to therapy. In view of the different definitions for response in the relevant time period of TASCT studies, and the ongoing discussion on whether a (best) response analysis allows a demonstratration of (durable) benefit for all patients, response was not assessed for the present review (Harousseau 2009a; Moreau 2011) (see Differences between protocol and review). Treatment- or transplant-related mortality, sometimes indiscriminately abbreviated as TRM in the original reports, was to be analysed as a measure of safety (see Differences between protocol and review).

\section{Search methods for identification of studies}

Evidence on the efficacy and safety of TASCT compared to SASCT in the first-line treatment of MM was identified by systematic electronic searching for literature in two bibliographic databases (Cochrane Central Register of Controlled Trials (CENTRAL); MEDLINE) according to the recommendation by The Cochrane Collaboration (Dickersin 1994; Higgins 2011). We had to exclude the database EMBASE due to budgetary restrictions and considered only publications in English, French and German. Since CENTRAL is updated with randomised controlled trials from EMBASE through retrospective searches conducted by the UK Cochrane Centre, up to 2008, EMBASE was at least partially covered through CENTRAL in our review.

Since observational studies, for example registry reports, were to be included in addition to RCTs, the search filter was adapted accordingly (see Appendix 1 and Appendix 2). Overall, the sensitivity of the presented search was lower for observational studies compared to RCTs due to the choice of bibliographic databases (CENTRAL is enriched for RCTs only).

The systematic search was restricted in the years of publication with the starting point of 1995 in order to approximate the establishment of TASCT as first-line treatment of MM (Barlogie 1997). A pilot search was performed in 2007. The systematic search of the two bibliographic databases MEDLINE and CENTRAL was performed on 30th of April 2010. The search was updated on the 23rd of May 2011.

\section{Electronic searches}

Bibliographic databases (1995 to 2011)

See Appendix 1 for MEDLINE, and Appendix 2 for CENTRAL search strategy.

\section{Searching other resources}

\section{Databases of ongoing trials}

Further potential sources for identifying trials were asking clinical experts (personal communications by Alexander Greb, Roland Schnell) or by browsing reference lists and the following websites using keywords such as "myeloma AND transplantation".

www.myeloma.org.

www.onkodin.de.

www.clinicaltrials.gov.

www.controlled-trials.com.

In addition, the Deutsches Krebsstudienregister (German Cancer Trials Registry) and Google were searched using the names of the first or senior authors' of the included trials.

\section{Handsearches}

No additional handsearches were performed.

\section{Contact}

Authors of the all RCTs were contacted at least once by email or telephone, or both, for further information.

\section{Data collection and analysis}

Information from included studies is either presented by study in the Characteristics of included studies or by topic: baseline characteristics, treatment regimen, definition of endpoints, in Table 2 Table 3; Table 4; and Table 5, respectively. Quality of reporting and extent of uncertainty due to missing information was captured for all included studies (Table 6).

\section{Selection of studies}

Studies were selected in two steps by one researcher (Figure 1). An independent meta-analysis published in 2009 and a health technology assessment (HTA) report published in 2011 were regarded as control for the comprehensiveness of the search (Kumar 2009; IQWIG N05-03C). Evidently irrelevant studies (such as animal 
experiments, other treatment approaches for MM or narrative reviews) were excluded by screening the title and abstract of the reference identified. The decision was based on the full-text publication in the case of uncertainty. Selected studies were assessed with an eligibility form as to whether they meet all inclusion criteria and none of the exclusion criteria (Table 1). 
Figure I. Study flow diagram.

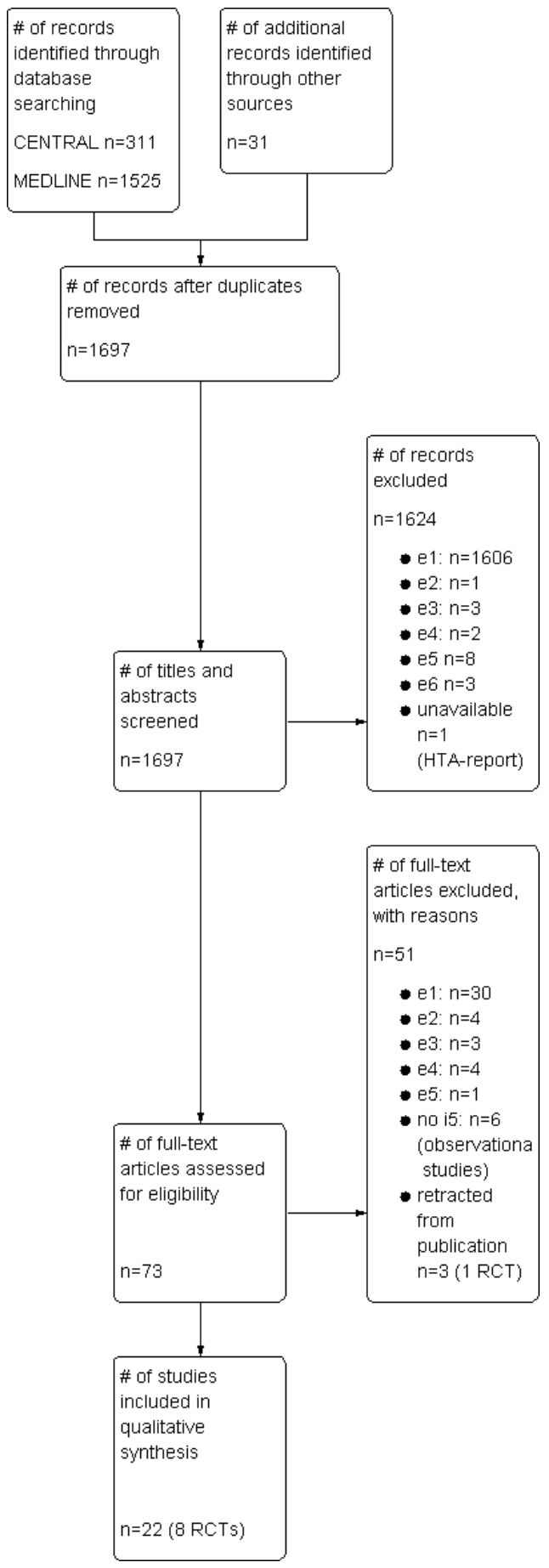

First-line tandem high-dose chemotherapy and autologous stem cell transplantation versus single high-dose chemotherapy and autologous stem cell transplantation in multiple myeloma, a systematic review of controlled studies (Review) Copyright (C) 2012 The Cochrane Collaboration. Published by John Wiley \& Sons, Ltd. 


\section{Data extraction and management}

Data extraction tables were developed in order to provide a clear framework for the verifiable collection of data items. Data items included both elements from prospective planning of the study (for example the hypothesis for sample size calculation) as well as the actual experience of the trial (for example compliance with intended treatment). The following information was collected by one researcher (FN) and the correctness of the extracted data was checked for accuracy by another researcher (RS).

Information on study basics such as the setting of the trial (time period, location), design, basis for sample size calculation, an intention-to-treat analysis (ITT) and number of patients dropping out, notable inclusion or exclusion criteria, type of reported outcomes relevant for the present review, and type of publication are described in the Characteristics of included studies. The most important aspects for interpretation of the individual study (as discussed also in the bias section) are also repeated as 'Notes'.

Information from the included trials regarding the following characteristics were grouped per topic (rather than by individual trial) in order to facilitate the comparison of one feature across all included trials.

- Baseline characteristics of patients (n, age, $\beta 2$ microglobulin, sex, stage, status at randomisation, type and number of prognostic factors reported) were extracted for all included studies (Table 2).

- Intervention details (type of stem cell mobilisation and source of stem cells, induction, conditioning, maintenance and salvage treatment) were noted with the aim of highlighting clinically relevant differences in the treatment regimen between study arms and between studies, and their deviance from current treatment standards. The compliance with the intended treatment schedule and the extent of cross-over (if reported) were also extracted (Table 3).

- Definitions of outcome measures (OS; EFS: starting point of the analysis for time-to-event data, definition of relevant events including the extent of follow up (Table 4); so-called TRM: definition of numerator (cause of death) and denominator (type of population), period of observation and additional causes of death reported in the study) were summarised for all included studies (Table 5). See also Differences between protocol and review.

- Results concerning both benefit (OS, EFS) and harm (socalled TRM or early mortality) of the individual trials were extracted.

\section{Assessment of risk of bias in included studies}

The quality of included trials was critically evaluated according to methodological criteria listed in Table 6. Several of these criteria were shown empirically to have an impact on the validity of trial results and are listed, for example in the CONSORT statement, the Cochrane Handbook for Systematic Reviews of Interventions using RCTs or in the STROBE statement for observational studies (Juni 2001; Moher 2001; von Elm 2008; Higgins 2011). In addition, characteristics regarded as essential for the interpretation of trials studying TASCT were discussed, for example acute toxicity of the treatment regimen or compliance with the treatment plan. A colour code was applied for the risk of bias table (Figure 2) in order to indicate compliance with (green) or missing (red) high quality standards (Table 6), while lack of information was coded with yellow. The quality of all studies which were deemed eligible for the review were systematically assessed by one researcher (FN) and discussed with the senior author (RS).

First-line tandem high-dose chemotherapy and autologous stem cell transplantation versus single high-dose chemotherapy and 
Figure 2. Overview of Risk of bias in the set of included trials: Green colour indicates sufficient information available to verify adequate methods or similar features in both study arms. Red colour is used to highlight characteristics which were systematically different between study arms and therefore may result in a biased comparison (both conservative or anti-conservative). Yellow colour indicates lack of (sufficiently detailed) information.

\begin{tabular}{|c|c|c|c|c|c|}
\hline Criteria & IFM94 & MAG95 & Bologna96 & GMMG-HD2 & DSMM-I \\
\hline \multicolumn{6}{|c|}{ Quality of design and methods } \\
\hline \multicolumn{6}{|l|}{$\begin{array}{l}\text { Central } \\
\text { randomisation }\end{array}$} \\
\hline \multicolumn{6}{|l|}{$\begin{array}{l}\text { Concealment of } \\
\text { allocation }\end{array}$} \\
\hline $\begin{array}{l}\text { Statistical power } \\
\text { for OS }\end{array}$ & $\begin{array}{l}\text { Under- } \\
\text { powered }\end{array}$ & & $\begin{array}{l}\text { Under- } \\
\text { powered }\end{array}$ & & \\
\hline \multicolumn{6}{|l|}{ Standardisation } \\
\hline Data maturity & & & & & immature \\
\hline \multicolumn{6}{|l|}{$\begin{array}{l}\text { Definition of } \\
\text { endpoints }\end{array}$} \\
\hline Publication type & & $\begin{array}{l}\text { Conference } \\
\text { presentation }\end{array}$ & & $\begin{array}{l}\text { Conference } \\
\text { presentation }\end{array}$ & $\begin{array}{l}\text { Conference } \\
\text { presentation }\end{array}$ \\
\hline $\begin{array}{l}\text { Further notable } \\
\text { issues }\end{array}$ & $\begin{array}{l}2 \times 2 \text { factorial } \\
\text { design } \\
\text { (no } \\
\text { interaction) }\end{array}$ & $\begin{array}{l}2 \times 2 \text { factorial } \\
\text { design } \\
\text { (with } \\
\text { interaction) }\end{array}$ & $\begin{array}{l}20 \% \text { DS stage I } \\
\text { MM }\end{array}$ & $\begin{array}{l}\text { optional } 2^{\text {nd }} \\
\text { random.: VID } \\
\text { vs VAD } \\
\text { (interaction?) }\end{array}$ & $\begin{array}{l}\text { TASCT as } \\
\text { control }\end{array}$ \\
\hline \multicolumn{6}{|c|}{ Potential of confounding or null-bias } \\
\hline \multicolumn{6}{|l|}{$\begin{array}{l}\text { Confounding at } \\
\text { baseline }\end{array}$} \\
\hline $\begin{array}{l}\text { Imbalance in } \\
\text { subsequent }\end{array}$ & $\begin{array}{l}\text { total }<17 \% \\
\text { thalidomide }\end{array}$ & NR & $\begin{array}{l}\text { total }>50 \% \\
\text { novel agents }\end{array}$ & $\begin{array}{l}\text { total }>40 \% \\
\text { novel agents }\end{array}$ & NR \\
\hline \multicolumn{6}{|l|}{ ITT analysis } \\
\hline $\begin{array}{l}\text { Compliance with } \\
\text { 2nd ASCT }\end{array}$ & $78 \%$ & & $65 \%$ & $52 \%$ & \\
\hline \multicolumn{6}{|l|}{$\begin{array}{l}\text { Completeness of } \\
\text { follow-up }\end{array}$} \\
\hline Cross-over & & & & & $20 \%$ to TASCT \\
\hline \multicolumn{6}{|c|}{ Treatment regimen } \\
\hline $\begin{array}{l}\text { Comparability of } \\
\text { regimen }\end{array}$ & $\begin{array}{l}\text { "Dose- } \\
\text { escalating" }\end{array}$ & $\begin{array}{l}\text { "Dose- } \\
\text { escalating" }\end{array}$ & & & \\
\hline $\begin{array}{l}\text { Risk of bias } \\
\text { concerning fair } \\
\text { comparison of } \\
\text { TASCT vs SASCT } \\
\text { from current } \\
\text { perspective }\end{array}$ & $\begin{array}{l}\text { High } \\
\text { (confounding) }\end{array}$ & $\begin{array}{l}\text { High } \\
\text { (confounding) }\end{array}$ & $\begin{array}{l}\text { Moderate } \\
\text { (null bias for } \\
\text { OS and EFS; } \\
\text { OS } \\
\text { confounded) }\end{array}$ & $\begin{array}{l}\text { Moderate } \\
\text { (null bias } \\
\text { for OS and } \\
\text { EFS; OS } \\
\text { confounded) }\end{array}$ & $\begin{array}{l}\text { High? } \\
\text { (immature, i.e. } \\
\text { unstable } \\
\text { results) }\end{array}$ \\
\hline Explanation & $\begin{array}{l}\text { "dose- } \\
\text { escalating" } \\
\text { regimen in } \\
\text { TASCT with } \\
\text { substantial } \\
\text { non- } \\
\text { compliance } \\
\text { with TASCT }\end{array}$ & $\begin{array}{l}\text { "dose- } \\
\text { escalating" } \\
\text { regimen in } \\
\text { TASCT; high } \\
\text { early mortality } \\
\text { in SASCT arm }\end{array}$ & $\begin{array}{l}\text { Steep decline } \\
\text { in compliance } \\
\text { with } 2 \text { nd } \\
\text { ASCT; high } \\
\text { proportion of } \\
\text { novel agents } \\
\text { as salvage }\end{array}$ & $\begin{array}{l}\text { Steep decline } \\
\text { in compliance } \\
\text { with } 2 \text { nd } \\
\text { ASCT, high } \\
\text { proportion of } \\
\text { novel agents } \\
\text { as salvage }\end{array}$ & $\begin{array}{l}\text { Insufficient } \\
\text { follow-up }\end{array}$ \\
\hline
\end{tabular}




\section{Measures of treatment effect}

No meta-analysis has been performed for the comparison of TASCT with SASCT (see Differences between protocol and review). Results from individual studies are presented in tables aimed at standardising highly variable reporting (Table 7). In addition, results are summarised as a narrative (Effects of interventions).

\section{RES U L T S}

\section{Description of studies}

See: Characteristics of included studies; Characteristics of excluded studies; Characteristics of ongoing studies.

\section{Results of the search}

Overall, 1697 potentially relevant articles, abstracts or conference presentations were identified by systematic searching for both randomised and non-randomised controlled studies in CENTRAL and MEDLINE. The comprehensiveness of our search was confirmed since all studies that were included either in the recently published meta-analysis or the HTA report on TASCT (Kumar 2009; IQWIG N05-03C) were also identified by our search. A flow chart of the systematic search for eligible studies is presented in Figure 1 according to the recommendations of the PRISMA statement (Moher 2009).

Twenty-two references dealt with our research question and were eligible for the systematic review according to pre-specified inclusion and exclusion criteria (Table 1), representing eight RCTs in total. One additional RCT had been retracted from publication and was therefore not included (Abdelkefi 2008; Abdelkefi 2009). Five RCTs were eligible for inclusion in a meta-analysis while three were ineligible, for various reasons. One RCT was identified as ongoing (currently recruiting patients) so that no data were yet available NCT01109004. Two trials (DM00-196 and N0265041749) were reported as completed or terminated in clinical trial registries but no publications with clinical outcome data were available. One abstract on DM00-196 focused on the reasons for withdrawal from the treatment protocol (Wilson 2003). N0265041749 had been registered as completed in the UK national registry but remained unpublished. The principal investigator of N0265041749, when contacted for further information, explained that the study had been closed due to insufficient recruitment. No further information was obtained after having contacted the authors of the other RCTs.
All of the five otherwise eligible comparative observational studies (Lahuerta 2003; EBMTR; Kim 2009; Koren 2010; NMSG) were excluded from the systematic review since they did not sufficiently describe the included patient population and applied treatment regimen (see Excluded studies).

\section{Included studies}

\section{Description of individual trials}

In the following sections, the characteristics of the included studies with outcomes relevant to the systematic review are briefly summarised individually (Characteristics of included studies). Further information on the trial design and performance is summarised below (comparison of characteristics of studies) and listed in detail (Table 2, Table 3, Table 4, Table 5). The results of individual studies are described in the section Effects of interventions and Table 7 , both sections aiming at standardising highly variable reporting.

- IFM94: Attal and colleagues selected 399 patients younger than 60 years with symptomatic disease predominantly of DurieSalmon (DS) stage II and III. Patients were randomised before induction treatment by a $2 \times 2$ factorial design to: a) TASCT or SASCT and b) bone marrow or peripheral blood stem cells. Treatment groups were reported to have similar baseline characteristics (Table 2). Transplantation regimens differed between the first and second ASCT in the TASCT arm (Table 3).

- MAG95: patients with MM (stage II and III) younger than 56 years were selected for MAG95 (Table 2); 227 patients were randomised before induction treatment by a $2 \times 2$ factorial design between: a) TASCT or SASCT and b) selection of CD34+ positive cells from peripheral blood stem cell grafts, or no selection (Table 3). Treatment groups were reported to have similar baseline characteristics (Table 2). Transplantation regimens differed between arms and between the first and second transplantation in the TASCT group (Table 3).

- The Bologna96 trial also assessed the concept of TASCT compared to SASCT in 321 patients younger than 60 years with symptomatic MM stage I, II and III. Patients were randomised before induction treatment to either one or two ASCT with similarly dosed preparative regimens (Table 3). Treatment groups were reported to have similar baseline characteristics (Table 2).

- The GMMG-HD2 included between 358 and 485 patients with DS stage II and III MM younger than 66 years (numbers inconsistent between different conference presentations). While only patients with at least stable disease were randomised between one or two ASCT with identical preparative regimens (Table 3), an optional randomisation between two induction regimens was reported for this trial. It remained unclear whether

First-line tandem high-dose chemotherapy and autologous stem cell transplantation versus single high-dose chemotherapy and 
the randomisations were performed and analysed under the same protocol. Treatment groups were reported to have similar baseline characteristics (Table 2).

- DSMM-I evaluated a novel conditioning regimen including bone marrow irradiation preceding SASCT and compared it to the 'standard' TASCT regimen as control (Table 3). Overall, 198 patients younger than 60 years with SD stage II and III disease were randomised if they had at least stable disease after induction and had successfully mobilised a sufficient number of stem cells. Treatment groups were reported to have similar baseline characteristics (Table 2).

\section{Comparison of characteristics of studies}

In the following section, general observations on the set of included trials are discussed with reference to more detailed tables on baseline characteristics (Table 2), treatment regimen (Table 3), and definition of endpoints (Table 4; Table 5).

\section{Baseline characteristics of included patients}

Information on allocation was limited for the majority of studies. All authors documented the similarity of study groups however, either by referring to $P$ values or by presenting similar values for selected prognostic factors. The only prognostic factors described for all studies were age, $\beta 2$-microglobulin and stage (Table 2). For MAG95, baseline characteristics of treatment arms were not reported separately. While MAG95 included the youngest patient population of the set of included trials, the Bologna96 trial included the highest proportion of patients with symptomatic stage I disease. In DSMM-I and GMMG-HD2, only patients responding to induction treatment were included. No obvious hierarchy concerning baseline risk between studies could be determined in view of the heterogeneity of eligible age range, stage or prognostic factors.

\section{Treatment plan and compliance}

None of the included trials assessed exactly the same treatment strategy. All trials deviated from what would be considered standard today in at least one component of the ASCT regimen (SASCT or TASCT). Different combinations or sequences of induction, mobilisation, conditioning or maintenance regimen were used. Rather than repeating one ASCT regimen, the TASCT regimens used in IFM94 and MAG95 could be described as doseescalating since the intensity of the preparative regimen used for the initial ASCT was lower than for the second ASCT. Compliance was usually high with the first or only transplantation in all trials but was highly variable for the second transplantation (Table 3). Causes of non-compliance were either myeloma-, toxicity- or procedural-related, or were based on patients' preferences: patients developed contra-indications for second transplantation while on the trial, or an insufficient number of stem cells precluded further
ASCT. A notable number of patients refused further treatment or were denied coverage. Among the reported reasons for non-compliance, refusal by patients was the most common reason for not performing the second transplantation. The lowest compliance with second transplantation was observed in Bologna96 (65\%) and GMMG-HD2 (52\% of evaluable patients).

Information on maintenance or salvage treatment (treatment after relapse) was limited for the majority of trials. First, it was often not reported separately for the two arms (DSMM-I; GMMGHD2; MAG95) and second, only proportions of types of salvage treatment were reported but not the outcome. Patients crossingover to the other treatment arm were only reported for DSMM-I, where $18 \%$ of patients from the SASCT crossed over to the TASCT arm without information on their status at the time of cross-over.

\section{Assessment of treatment effect}

Although heterogeneity of disease and potential differences in response criteria existed (locally or over time), no trial reported on efforts of standardisation across the usually high number of study centres (see Characteristics of included studies).

\section{Excluded studies}

\section{Randomised trials}

Sonneveld 2007 was excluded from the systematic review due to the non-myeloablative approach of intermediate dosing of melphalan in the control arm (two times $70 \mathrm{mg} / \mathrm{m}^{2}$ melphalan instead of one high dose of melphalan $140 \mathrm{mg} / \mathrm{m}^{2}$ ).

\section{Observational studies}

Comparative observational studies were to be included in the trials if both the population and treatment regimen were described in sufficient detail. None of the observational studies identified allowed us to adequately assess or rule out 'confounding by indication', the most critical issue for interpretation of treatment effects from observational studies (Kunz 1998; Vandenbroucke 2008). Therefore those data, mostly registry data (EBMTR; Kim 2009; NMSG) or single centre experience (Lahuerta 2003; Koren 2010), were not formally included in this systematic review.

\section{Total therapy (no RCT)}

TASCT is an integral part of 'Total therapy' (TT), developed by Barlogie and colleagues (Total therapy). TT publications were not included in the systematic review for the following reason: TT was supported by an historical comparison of a single-armed study in a single specialised centre, both initially (TT1; Barlogie 1997) and upon development of further TT generations (Barlogie 2009). 
With this design, selection bias at enrolment and potentially informative censoring during study conduct can neither be assessed nor excluded. Of note, all generations of the total therapy program, except TT1, integrate the so-called novel-agents either before or after TASCT, or both, which is regarded as a critically different treatment approach compared to that in the set of included RCTs (Barlogie 2006)

\section{Risk of bias in included studies}

Assessment of the potential of bias was based on several methodical aspects and actual experience during (for example compliance) or after the performance of the trial (for example publication type) (Table 6; Figure 2).

Most information was available for classification of risk of bias for IFM94 and Bologna96, which were published as full-text publications, compared to the trials available as conference presentation only (DSMM-I; GMMG-HD2; MAG95). The quality of the trials was rated both according to prospective elements such as the availability of an ITT analysis, the reported basis for sample size calculation or whether a detailed description of the baseline would allow the reader to rule out clinically relevant if not statistically relevant differences in baseline characteristicss (see Figure 2).

Bias was also assessed based on the time point of analysis, that is the extent of follow-up or data maturity. There is consensus that minimal median follow-up in MM should be more than four years (Harousseau 2009a; Tricot 2009). RCTs with follow-up of more than four years were marked in green, while trials with less or insufficient information were coded in red or yellow (see Figure 2). Since neither conference presentations nor abstracts contained sufficient data to ascertain the validity of the results, the lack of a full-text publication was also rated as a negative feature (Tam 2008).

The overall potential for bias (direction of bias unclear) was rated per study (Figure 2) based on the most important factors involved (Table 6). With respect to individual endpoints, OS was considered to be more biased compared to EFS and so-called TRM since, in addition to transplantation regimen and compliance (see Other potential sources of bias), follow-on treatment could have impacted on the effect on OS.

IFM94, MAG95 and DSMM-I were considered as having the potential to be highly biased, with an unclear direction of bias (conservative or anti-conservative). Most relevant issues for the classification of IFM94 were the dose-escalating TASCT regimen (Other potential sources of bias), low compliance with the second ASCT and unclear type and effect of follow-on treatment (Table 3). The critically limited amount of information due to its publication type (Selective reporting), together with TASCT and SASCT regimens which would be regarded as non-standard today (Other potential sources of bias), were decisive for classifying MAG95 as potentially highly biased. In view of its relatively short follow-up, apparently unstable results with multiple crossings at the right end of the Kaplan-Meier curves and high cross-over rate, DSMM-I was also rated as having the potential to be highly biased, with an unclear direction of bias.

Since Bologna96 and GMMG-HD2 (at least) evaluated a standard-dose TASCT conditioning regimen from a contemporary perspective, they were (rather subjectively) rated as moderately biased despite the steep decrease in compliance with the second ASCT (see also Discussion).

\section{Allocation}

Information on allocation was limited for the majority of studies (see Characteristics of included studies). While all reports were reported as randomised, only the full-text articles of IFM94 and Bologna96 allowed the assessment of procedural aspects of randomisation which are necessary to judge whether, for example, concealment of allocation would be achieved, or not.

\section{Blinding}

In view of the obvious differences in treatment plan, none of the studies were blinded. This is acceptable for ethical reasons but heightens the importance of objective outcome assessment.

\section{Incomplete outcome data}

The steep decrease in compliance with the second ASCT most likely results in a null bias, that is a conservative shift of the treatment effect in an ITT analysis. The overall shift of the treatment effect was, however, unclear in view of the dilution of effects by non-compliance, unpredictable selection bias of compliant patients and further confounding by salvage treatments (Schulz 2002; Wheatley 2006).

ASCT as first-line treatment of MM was followed by further lines of therapy as salvage treatment in case of relapse or progression (see Table 3). Since all included RCTs coincided with the clinical development of several so-called 'novel agents' with considerable activity in myeloma, the type and outcome of follow-on treatment is critically important for the interpretation of OS. Information on the type of salvage treatment per arm, if at all available, was insufficient for all trials. No or limited information was available concerning completeness of follow-up or cross-over (before an event) for most RCTs.

\section{Selective reporting}

Both the reported items and printing quality differed widely between full-text publications, abstracts and conference presentations. Endpoints were only superficially defined in most trials, with only Bologna96 referring to censoring rules in time-to-event analyses(Table 4). Kaplan-Meier (KM) curves were not available for OS in the full-text publication of Bologna96 and not for EFS in the conference presentation of MAG95. 
Both definitions of the relevant period of observation and causes of death to be listed as so-called TRM remained unclear in the majority of trials (indicated by depicting the latter as 'so-called TRM') (Table 5). Only interim data on 'toxic death' were available for MAG95 (see Discussion). In addition, mainly proportions (and not number of deaths in a specified population) were reported in the majority of trials, leaving room for interpretation concerning the denominator used for the calculation of the proportions, which is especially important in view of usually lower compliance with the second transplantation (Table 3).

Only those studies in which statistically significant improvements in survival outcomes were observed were published as full-text publications (IFM94; Bologna96) while the non-significant results of three further RCTs were available on the Internet as conference presentations only (MAG95, GMMG-HD2, DSMM-I). Two RCTs remain unpublished in spite of being registered as terminated (DM00-196; N0265041749). According to the principal investigator, DM00-196 was closed due to insufficient recruitment. The dependency of publication on the size of the treatment effect (and the associated statistical significance) is an obvious sign of publication bias which could only be detected by a meticulous literature research or interaction with experts who had been aware of the trials during their performance.

Selective reporting of outcomes, apart from uncertainty due to unclear definitions (see Incomplete outcome data; Table 4; Table 5), was not observed for the endpoints considered for this systematic review.

\section{Other potential sources of bias}

\section{Impact of treatment plan and compliance}

While the cumulative dose was higher in the TASCT arm for all studies, dose density differed notably between TASCT and SASCT in IFM94, MAG95 and DSMM-I. When assessing the comparability of treatment toxicity between the SASCT and TASCT regimens within studies, some SASCT regimens were considerably more toxic, either overall (DSMM-I) or at an earlier time point (with higher dose density), compared to a sort of doseescalating scheme in the TASCT arm with 'softer' conditioning for the first ASCT (Table 3 ). Total body irradiation (TBI) was omitted for conditioning before the first ASCT in the TASCT arm of IFM94, while the second ASCT was identical to the only ASCT in the SASCT arm. The first ASCT for the TASCT arm in MAG95 involved an overall lower dose of chemotherapy without TBI and CD34-selection in contrast to the only transplantation in the SASCT arm. Twice as many patients died early in the group receiving CD34-selected grafts in MAG95 $(\mathrm{N}=14$ versus $\mathrm{n}=7)$. In view of the treatment plan for MAG95, with differences in the timing and intensity of treatment regimens (Table 3), a clinically relevant interaction between CD34-selection and randomisation to the TASCT or SASCT arm was likely.
On the one hand, delayed onset of intense chemo(radio)therapy may initially favour the TASCT arm in the trials with respect to sparing patients' acute toxicity (potential lead time bias). On the other hand, insufficient dose intensity up to and including the first ASCT may leave patients who discontinue prior to second transplantation undertreated. This is especially important for IFM94, in which the compliance with the second transplantation was only $78 \%$. The possibility of these biases was coded with a red colour (Figure 2; see also Incomplete outcome data (attrition bias).

Cross-over from the SASCT to the TASCT arm was only reported for the DSMM-I trial (18\% cross-over) while no information was available about the time point of crossing-over (before or after progression). Cross-over also confounds the reported results by potential null and selection bias.

\section{Effects of interventions}

Initially, we planned to perform a meta-analysis of the five included studies: all trials were comparing TASCT with SASCT as first-line treatment of symptomatic MM in patients who were either untreated or had received conventional treatment, that is non-highdose chemotherapy, for a maximum of six months. Features of the treatment regimen and obvious biases introduced during study performance (compliance, interaction, course of events in control group) stopped us from conducting a formal meta-analysis however (Differences between protocol and review). In order to summarise the results of the individual studies, the number of events and survival proportions are both listed in Table 7 and recapitulated in a standardised way in the section below. The time course observed in the Kaplan-Meier (KM) curves (not available for OS in Bologna96, EFS in MAG95) was added in order to transmit the maximum amount of information from the individual trials into the systematic review.

Quality of life was not reported for any included study, which is deplorable in view of the known adverse effect of ASCT on quality of life (Campagnaro 2008; Jones 2008). Furthermore, late toxic effects of ASCT, such as secondary malignancies or infections, were not specifically reported in any trial (Jantunen 2006; Majhail 2008).

In IFM94 a statistically significant benefit for the tandem arm on both OS and EFS was observed after a median 75 months of follow-up: Median EFS and OS were prolonged by TASCT from 25 to 30 months and from 48 to 58 months $(\mathrm{P}=0.03$ and $\mathrm{P}=0.01$, respectively). Seven-year OS (21\% versus $42 \%)$ and EFS (10\% versus $20 \%$ ) proportions also significantly favoured the tandemtransplantation group (Table 7). A trend for improved survival was observed in the long-term follow-up analysis, with a median 11.6 years of follow-up (OS P $=0.08$; EFS $\mathrm{P}=0.06$ ). No difference between the second randomisation option (bone marrow versus peripheral blood stem cells) was observed. Exploratory subgroup analysis suggested that patients who benefited most from the TASCT were those who did not achieve at least a very good 
partial response after their first transplantation. It is important to note that the first ASCT in the TASCT arm was performed with a lower dose (140 mg/m² melphalan) compared to the only ASCT in the SASCT arm (140 mg melphalan and TBI) (Table 3 ) and may therefore be classified as underdosed from a contemporary perspective. This is of relevance in view of only $78 \%$ of patients in the TASCT arm actually undergoing the second transplantation. Treatment-related mortality was observed in $6 \%$ of the TASCT and $4 \%$ of the SASCT $\operatorname{arm}(\mathrm{N}=12$ versus $\mathrm{N}=8)$, of which $\mathrm{N}=$ 5 (TASCT) and $\mathrm{N}=3$ were related to the transplantation-related complication sepsis. Overall, seven different causes of death were specified (Table 5). Similar two-year survival proportions were observed for patients after relapse in SASCT and TASCT, although imbalances in salvage treatment limit the interpretability of the results (see Table 3; Assessment of risk of bias in included studies). In MAG95, after a median follow-up of 73 months OS appeared superior in both the TASCT group compared to the SASCT group (randomisation option A) and in the group receiving unselected grafts compared to those receiving selected grafts (randomisation option $\mathrm{B})(\mathrm{P}=0.09$ and $\mathrm{P}=0.33$, respectively) (Table 7$)$. The prolongation of the median OS from 57 to 75 months in the TASCT arm might be misleading due to the position of the median at the right end of the Kaplan-Meier graph with very few patients at risk. Only a slight prolongation of median EFS was reported for the TASCT arm (34 versus $31 \mathrm{mo}$ ). In the subgroup of patients who had received unselected grafts, OS was statistically significantly improved in the TASCT arm compared to patients in the SASCT arm $(\mathrm{P}=0.04)$, highlighting the potential interaction of CD34-selection and mortality (Assessment of risk of bias in included studies; Awedan 2002). Only interim data were available for MAG95 concerning toxic deaths, based on $85 \%$ of the final study population. For the final analysis, early deaths which included myeloma-related deaths (TASCT 7\% versus SASCT 12\%) were reported.

The time-course of mortality as seen in the Kaplan-Meier graph for MAG95 revealed two clusters of events in the control group which appeared to drive the overall difference between the SASCT and TASCT arms. The first of the two clusters of events in the control arm (two to four months post-randomisation) coincided with the treatment phase of the trial with an almost doubled early mortality in the SASCT arm (Table 7). In the MAG95 trial, patients in the TASCT group received the selected graft only at the second ASCT, while the graft used for the first ASCT was unselected (Table 3; Assessment of risk of bias in included studies).

Bologna 96 did not confirm the significant OS benefit as observed in the IFM94 trial for TASCT in an ITT analysis $(\mathrm{P}=0.9)$. While the median OS was extended from 65 (SASCT) to 71 (TASCT) months, seven-year survival proportions were similar (43\% after TASCT versus $46 \%$ after SASCT). No Kaplan-Meier graph was available for OS. Five-year EFS was significantly better in the TASCT arm (29\% versus $17 \%)$ (Table 7$)$. The improvement in median EFS from 23 to 35 months in the TASCT group was statistically significant $(P=0.001)$ with a rather steep decrease in EFS in the control arm approximately 18 months after randomisation. The duration of relapse-free survival was prolonged from 24 months in the control group to 42 months in the tandem-transplantation arm. Post-relapse survival (PRS), however, favoured the SASCT arm with a median PRS of 32 months compared to 25 months in the TASCT arm. In view of the low compliance with the second transplantation in the TASCT group (65\%) (Table 3), the interpretation of results was hampered due to potential null and selection biases (Assessment of risk of bias in included studies). Subgroup analysis of patients not reaching complete remission after induction confirmed the observation of the IFM94 trial suggesting that patients who do not respond well to initial therapy benefited most from the double intensified protocol. Transplantation-related mortality (definition see Table 5) was reported as $4 \%$ in the TASCT and 3\% in the SASCT arm.

In GMMG-HD2, the final analysis did not demonstrate a significant prolongation of the median EFS (29 versus 25 mo; no P value provided) (Table 7). The Kaplan-Meier curves for EFS in GMMG-HD2 in the ITT population separated only transiently between 18 months and 38 months (TASCT superior) but the final proportions of patients surviving event-free were similar (if more than 10 patients still at risk). Kaplan-Meier curves for OS, for the ITT population were superimposable. In view of a very low compliance with the second ASCT (52\% of evaluable patients) (Table 3), per protocol (PP) analyses were performed in addition to the ITT analyses (see also Assessment of risk of bias in included studies). While the per protocol (PP) analysis of EFS was similar to the ITT analysis, the PP analysis of OS indicated numerically inferior survival for the TASCT arm over the majority of the follow-up period (Discussion). So-called TRM (definition see Table 5) was reported as $2 \%$ during the first and $3 \%$ during the second transplantation compared to $2 \%$ in the SASCT group (Table 7). In DSMM-I, with a follow-up of approximately 48 months (corresponding to the entire time axis in the Kaplan-Meier graph) the Kaplan-Meier curves appeared unstable with multiple crossings for OS and EFS and a flattening of the curves at the right end (Assessment of risk of bias in included studies). While OS, EFS and PFS all appeared superior for the TASCT group, final survival proportions were favourable for the SASCT arm (Table 7). Kaplan-Meier graphs presented later (Einsele 2007), indicated that PFS was consistently higher for the SASCT arm. No information was reported with respect to the type of analysis (ITT, PP, subgroup analysis?). So-called TRM (definition see Table 5) was reported as $4 \%$ for the TASCT and 3\% for the SASCT arm. The definition of so-called TRM remained unclear. Notably, OS in the TASCT arm remained at $100 \%$ for 400 days (including treatment phase? ) in the TASCT arm (Table 7).

\section{I S C U S S I O N}

First-line tandem high-dose chemotherapy and autologous stem cell transplantation versus single high-dose chemotherapy and 
Empirical research should always take into account previous experience, either to build on it, refute it, or at least to learn from it (Clarke 2004; Chalmers 2009). Systematic reviews or meta-analysis are formalised tools to review available evidence on a clearly defined question. They are also an occasion to systematically and rigorously assess the quality of the available evidence (Egger 2001).

The findings of a comparison of two treatments, that is the treatment effect, may result from a) improvement of an outcome by the test treatment, b) an inferior outcome of the control treatment, c) a chance finding, or even in the setting of a RCT d) be driven by confounding factors within a small and heterogeneous patient population (Blair 2004). All four options should be addressed in the course of an exploratory systematic review. Both patient characteristics and study design (including the treatment plan) should be scrutinised for their propensity to favour one or more of the four possibilities. While a systematic review as a retrospective observational study cannot settle a controversy, the examination may help to contribute to the design of future studies addressing (an emerging) one.

\section{Summary of main results}

In the set of publicly available RCTs performed between 1994 and 2002 (five of seven completed RCTs), TASCT was accompanied by a statistically significant improvement in OS compared to SASCT for the first-line treatment of patients with MM in one study only (IFM94; statistical significance not confirmed in longterm follow-up). In the other four trials it appeared to have no effect on survival (Table 7). None of the studies were adequately powered for the analysis of OS and considerable confounding due to varying access to salvage treatment is likely. Of note, OS appeared numerically inferior for the per protocol population of the GMMG-HD2 trial, which may be due to the selection of patients who proceeded to second transplantation. An observational study with matched pair design also reported on numerically inferior OS (NMSG), as well as a reported case series from a single centre experience (Koren 2010), highlighting the necessity to further study the impact of the second transplantation on long-term outcomes. TASCT improved EFS compared to SASCT in four of the five trials (not in DSMM-I) (Table 7), but the effect was statistically significant only in the two trials published as full-text articles ( IFM94; Bologna96). The beneficial effect on EFS appeared to be transient in GMMG-HD2. The results of DSMM-I appeared to be too immature to allow firm conclusions.

Treatment- or transplant-related mortality, sometimes indiscriminately summarised as so-called TRM, was higher for the TASCT arm in four of five studies without reference to statistical significance (all except MAG95). For MAG95, both the time course of events in the Kaplan-Meier graph and interim data indicate that here the SASCT regimen claimed more early and toxic deaths compared to the TASCT regimen.
Quality of life was not reported in any of the included studies. Response to treatment had not been assessed for the present review. In view of the observed heterogeneity of treatment concepts and the extent of potential bias in the individual studies, we refrained from performing a formal meta-analysis (Feinstein 1995). Critical features in the set of included trials concern major differences in the treatment plans, not only between but also within individual RCTs. Variable compliance with the planned treatment during performance of the trials and the potential confounding of OS data by subsequent treatment may also impact on the observed treatment effect. Overall, the direction of bias was considered as unpredictable (Risk of bias in included studies; Quality of the evidence; Figure 2).

\section{Overall completeness and applicability of evidence}

\section{Publication bias}

Two completed or terminated RCTs were identified in clinical trials registries, however they remained unpublished. For the only American trial (DM00-196), an interim analysis in abstract form reported on a critical lack of compliance with the second ASCT, without follow-up data (Wilson 2003). The UK-based study (N0265041749) reported on similar problems with accrual, which resulted in early closure of the trial (Mahendra personal communication). Three of the five included RCTs (DSMM-I; GMMG-HD2; MAG95) were available as conference presentations only, emphasising both the necessity to include non-full text information when systematically evaluating a treatment concept in oncology and the difficulty of accepting conference presentations in view of low reporting quality (Ramsey 2008; Tam 2008). Of note, only the two journal articles report statistically significant improvements in survival endpoints (IFM94; Bologna96), while the conference abstracts refer to non-significant results or to difficulty in actually performing the second transplantation (Hopewell 2009). Overall, it appears as if only positive results of TASCT are published in widely accessible medical journals while the scientific community is not equally informed on disappointing results, concerning either practicability or clinical outcome.

On the one hand, lack of reporting of clinical outcome data is an obvious sign of publication bias, a well-known phenomenon in clinical research (Curt 2008; Ramsey 2008). On the other hand, the problems with either accrual of patients or low compliance with the protocol illustrates the strenuous nature of a TASCT regimen.

\section{Baseline characteristics}

Even in RCTs, relevant imbalances at baseline may help to explain the relative outcome of the study arms (Blair 2004). MM is a very 
heterogeneous disease and the evaluable set of of participants of some of the trials was only around 100 (compliant) patients per arm (DSMM-I; GMMG-HD2; Bologna96), which may be insufficient to balance out chance findings (Moore 1998). In addition, no information on cytogenetic characteristics was collected in the included trials. The cytogenetic information is regarded as critical for extrapolation of results, since cytogenetic analysis belongs to the basic workup for contemporary patients with MM (Munshi 2011).

\section{Treatment regimen}

When reviewing literature, it is important to take into consideration recent improvements in individual steps of the rather complex intervention of autologous stem cell transplantation (Awedan 2002; Attal 2007; Harousseau 2009a). Preparation of patients for ASCT has changed substantially during the last two decades, including induction treatment, mobilisation or handling of stem cells and a conditioning regimen for ASCT. While induction treatment used to be a combination chemotherapy with vincristine, doxorubicin and dexamethasone (VAD), or high-dose steroids, nowadays the so-called 'novel agents' have replaced the classical induction regimen (Lane 2005; NCCN 2011). Furthermore, for contemporary ASCT, only peripheral blood stem cells without graft manipulation (for example purging of tumour cells) are used for ASCT in view of better engraftment characteristics when compared to bone marrow (Gratwohl 2007). TBI has been largely abandoned as a conditioning regimen in view of increased toxicity (Moreau 2002; Tricot 2009). In addition, the conditioning regimen for the second ASCT in the TASCT arm included busulfan, which has recently been associated with a high treatment-related morbidity, possibly impacting on further access to salvage treatment (Lahuerta 2010). Today, $200 \mathrm{mg}$ melphalan is considered to be the standard conditioning regimen (Giralt 2010). It is important to note that the regimen used for both TASCT and SASCT followed the learning curve of the development of the standard regimens in use today, that is all regimens would be considered substandard from a contemporary perspective in at least one or even several components (Table 3).

Overall, treatment regimens were diverse in the included trials, with notable differences in toxicity between trials but also between study arms, thereby potentially biasing the overall results (leadtime bias). The low compliance with the second transplantation in three trials (IFM94, Bologna96 and GMMG-HD2) (see Table 3) makes the interpretation of treatment effect difficult in view of unassessable attrition bias, even more so as the TASCT regimen in IFM94 and MAG95 followed a sort of dose-escalating scheme. Both MAG95 and DSMM-I applied non-standard SASCT regimens to the control group, which also needs to be considered for the interpretation of data since treatment effects may stem from a superior test regimen or from an inferior control arm. Overall, the possibility of extrapolating the available evidence to treatment decisions for contemporary patients is questioned.

\section{Quality of the evidence}

For interpretation of the effect on OS, the following issues were regarded as critical in the course of the present systematic review: confounding by subsequent treatment (all studies), compliance with the second transplantation (IFM94; Bologna96; GMMGHD2), acute toxicity of control treatment (DSMM-I; MAG95), extent of cross-over (DSMM-I), and time course of mortality ( MAG95). The observed cluster of events in the control arm during the treatment phase of the only transplantation in the SASCT arm of MAG95 is indicative of an increased toxicity in the SASCT arm, that is an inferior outcome for the control arm.

For interpretation of the effects on EFS, the following issues were regarded as critical: extent of cross-over (DSMM-I), low compliance with the second transplantation (IFM94; Bologna96; GMMG-HD2). Furthermore, it remained unclear whether any of the studies made provisions to address relevant biases introduced by irregular or asymmetric assessments for events in the course of the EFS assessments (CHMP/EWP/27994/08 2008). In addition, events for EFS were defined differently between trials (Table 4) In the included trials both definitions of the relevant period of observation and causes of death to be listed as so-called TRM remained unclear, and were not comparable between trials (Table 5). Another uncertainty concerning the comparability of studyspecific results stemmed from the different level of sophistication of ascribed causes of death (for example IFM94). In addition, the definition of the population in which so-called TRM was reported as a percentage was missing for most trials. This is of relevance in view of the low compliance with second transplantation, since there may be large deviance between different populations in the analysis (for example ITT or 'as treated').

The short-term risk would need to be counterbalanced by a convincing prolongation of long-term survival accompanied by an improved quality of life. The per protocol population of GMMGHD2, a matched-pair analysis and a single-centre experience (GMMG-HD2; NMSG; Koren 2010), although all methodically contestable pinpoint to a potentially inferior survival outcome for patients actually undergoing second transplantation compared to a SASCT regimen. More information is required on the long-term benefit for patients in view of the overall strenuous treatment approach of TASCT.

\section{Agreements and disagreements with other studies or reviews}

Only one other meta-analysis on the same topic has been published (Kumar 2009). In their conclusion, Kumar et al advised against the routine use of TASCT in view of statistically significantly increased 
treatment-related mortality without significant prolongation of OS (Kumar 2009).

The discouragement of first-line TASCT triggered substantial criticism among US experts in MM, accompanied by a controversial discussion on the methods and interpretation of data in the meta-analysis (Giralt 2009; Mehta 2009; Tricot 2009). On the one hand, the clinicians commenting on the meta-analysis were disappointed that important clinical aspects had not been discussed in the course of the meta-analysis, for example the impact of salvage treatment, the use of TBI in the older trials or the different definitions of TRM in the set of included trials. On the other hand, the authors of the meta-analysis objected to methodically problematic proposals for analyses or interpretations of available evidence by the clinicians (Kumar 2009a; Kumar 2009b).

The present systematic review differs from Kumar 2009 in several aspects. First, with respect to the set of included trials, Kumar included Sonneveld 2007 which in our view is not assessing TASCT but rather a non-myeloablative double-intensified protocol (Excluded studies). DSMM-I, included in our analysis, was not mentioned by Kumar et al. While DSMM-I yielded indefinite results for all outcomes, Sonneveld reported statistically significant results for EFS (TASCT better) and TRM (TASCT worse).

Second, the focus of our qualitative assessment of included studies exceeded the prospectively planned elements (such as reporting of sample size calculations or definitions of endpoints) of trial design considered by Kumar et al. Here, we integrated both additional design elements of the trial into the assessment (for example acute toxicity of treatment regimen) as well as actually observed effects during trial performance (such as time course of mortality, compliance with treatment) (Other potential sources of bias).

While Kumar presented meta-analytical results, we considered the observed clinical and methodological heterogeneity as being too pronounced to gain further insights from a combined analysis. We agree with Kumar's conclusion that a short-term risk needs to be counterbalanced by a long-term benefit in order to justify routine use of a medical intervention. We also consider it likely that there is only a marginal, if any, beneficial effect of TASCT on OS. Thus, we agree in questioning the value of tandem autologous stem cell transplantation as a first-line treatment in MM. We hestitate to follow Kumar et al, however, with respect to the informative value of the increased TRM observed after TASCT. We raise the question that if an inevitably life-threatening procedure (ASCT) was performed twice instead of once, would we not even expect an at least doubled risk of transplantation-related mortality (Jones 2008)? In addition to the diversity of the defintions of TRM used (Table 5), the low compliance with the second transplantation (Table 3) may further complicate a definite analysis of treatmentor transplantation-related mortality.

We also deplore the low precision of reporting on this important outcome of patients' safety (Table 5). It remained unclear whether treatment- or transplant-related mortality was reported when the ambiguous abbreviation was used (GMMG-HD2; DSMM-I). Fi- nally, we do not agree with Kumar that TRM in MAG95 might have been so high that the authors refrained from reporting it. As described above, we even consider an exceptionally high mortality in the SASCT arm of MAG95 as plausible in view of the KaplanMeier graph of the final analysis, interim data on toxic death and the expected toxicity of the treatment regimen based on dose density (Other potential sources of bias; Effects of interventions).

Overall, we aimed at contributing to improvements of future trial designs on tandem transplantation rather than settling the conflicting evidence on TASCT, also considering the evolution of treatment approaches of MM in the last decade. We therefore elaborate in some detail on the difference of the treatment approaches to TASCT, then and now, and discuss further methodological issues that prevent clear-cut interpretation of data, especially for contemporary patients (Other potential sources of bias; Implications for practice; Implications for research). We doubt that these potentially confounding issues could be adequately addressed and recompensed in an individual patient data (IPD) analysis.

We regret to conclude that the set of available RCTs do not yield sufficient evidence for contemporary treatment decisions.

\section{A U THOR S' CONCLUSIONS}

\section{Implications for practice}

The present systematic review critically questions the validity of the included set of trials to provide a basis for contemporary treatment recommendations, especially for patients who have already achieved a good response after the first transplantation. Treatment of MM has changed dramatically in the past 15 years and there are considerable uncertainties and potential sources of bias in this rather old set of trials. In addition, the quality of reporting of trial methods and results, especially in those trials available as conference presentation only, do not allow us to draw firm conclusions.

The uncertainty in the medical community as to whether the acute toxicity of a second ASCT is counterbalanced by long-term benefit is also reflected in the design of a number of recent and ongoing trials, and current treatment guidelines. In view of the increase in the proportion of complete responses after a second transplantation in the set of included trials, the option of a second transplantation is sometimes limited to patients who have not responded optimally to the first transplantation (for example Kortüm 2010). The dependency of a second transplantation on a suboptimal response to first ASCT was already integrated into the unpublished DM00-196 trial, and into the current generation of studies performed by the IFM and GMMG study groups (for example GMMG-HD5 or Moreau 2011 studies). Also, Cavo highlights the necessity of evaluating the additional benefit of a second transplantation in view of the high complete response rates already obtained with the novel induction regimen (Cavo 2010).

First-line tandem high-dose chemotherapy and autologous stem cell transplantation versus single high-dose chemotherapy and 


\section{Implications for research}

The observation that, for various unavoidable reasons, compliance with a second transplantation decreased sharply needs to be taken into account for future trial designs. This finding is also supported with data described for 2655 patients in a TASCT program in the European Bone Marrow Transplantation Registry (EBMTR), for whom a compliance of only $55.3 \%$ was observed with the second ASCT (Morris 2004). Therefore, sample size calculations for studies assessing TASCT upfront (that is independent from response to treatment, such as the ongoing study (NCT01109004)) should take into account that patients may progress prior to or develop contraindications against a second ASCT, or simply refuse to undergo a second transplantation. This decrease in compliance cannot be considered at random thus strategies need to be developed which aim at addressing the expected selection of patients both fit enough and willing to continue to second transplantation (see also Wheatley 2006). Alternatively, patients who successfully underwent first transplantation (and for whom sufficient stem cells were collected before) could be randomised between different consolidation treatment options. While the latter option bears the risk of introducing selection bias in the absence of objective criteria to describe the relevant population, it may ultimately avoid the other biases described at length above.

In view of the difficulty in ascribing specific causes of death in a multimorbid patient population, we propose reconsideration of the definition of the important endpoint of treatment- or transplantation-related mortality in order to optimise its clinical utility. Rather than defining the numerator, that is the type of events which qualify as treatment-related (a challenging and potentially subjective process (Keirns 2008)), the reporting of all-cause mortality in a relevant period of time (such as 'from randomisation until three months after completion of intensive treatment') is proposed. Specific causes of deaths, such as fatal infection during aplasia, could additionally be reported for didactic purposes. Early mortality reflects either too toxic or ineffective treatment, both of which are undesirable for symptomatic patients in the need of treatment.

The publication bias, as determined for the RCTs comparing TASCT with SASCT, emphasises both the necessity and the difficulties in including non-full text information when systematically evaluating a treatment concept in oncology (Curt 2008; Ramsey 2008; Tam 2008). Reporting of trials still needs to be improved in order to allow at least an informed discussion on the potential direction of bias (Hopewell 2010).

\section{ACKNOWLEDGEMENTS}

We would like to thank the Cochrane Haematological Malignancies Review Group Editorial Team for their support.

\section{REF E R E NCES}

\section{References to studies included in this review}

\section{Bologna96 \{published and unpublished data\}}

Cavo M, Tosi P, Zamagni E, Cellini C, Tacchetti P, Patriarca

$\mathrm{F}$, et al.Prospective, randomized study of single compared with double autologous stem-cell transplantation for multiple myeloma: Bologna 96 clinical study. Journal of Clinical Oncology 2007;25(17):2434-41.

DM00-196 \{unpublished data only\}

Giralt S, MD Anderson Study Center. A Randomized Phase II Trial of tandem transplantation vs thalidomide/ dexamethasone maintenance therapy for patients with multiple myeloma failing to achieve complete remission after intensive induction therapy. http://utmext01a.mdacc.tmc.edu/dept/prot/clinicaltrialswp.nsf/Index/ DM00-196 2000 [accessed 22.2.2011].

Wilson RL, Gray ML, Giralt S. Barriers to second transplant for multiple myeloma in a randomised autologous tandem trial [IBMTR/ABMTR Participants' meeting, Keystone Colorado, January 2003]. Biology of Blood and Marrow Transplantation. 9 2003; Vol. 9, issue 2.

DSMM-I \{published and unpublished data\} Einsele H. Stem Cell Transplantation for MM: Analysis of Prognostic Factors[S9.3] [XIth International
Myeloma Foundation Workshop, Kos]. Haematologica. 2007; Vol. 90, issue s2:49 http://myeloma.org/pdfs/ Kos2007 ' Einsele.pdf [accessed 22.2.2011].

Einsele H, Liebisch P, Bargou R, Meisner C, Metzner B, Wandt $\mathrm{H}$, et al.Single high-dose chemoradiotherapy versus tandem high-dose melphalan followed by autologous stem cell transplantation: preliminary analysis [Xth International Myeloma Foundation Workshop, Sydney]. Haematologica. 90 2005; Vol. 90 Suppl 1:131.

Knop S. New approaches in first-line therapy - international perspective: 3. Germany - Younger patients [1st Wurzburg Myeloma Workshop 2008]. http://mds-forum.onkodin.del myelom2008/content/e54/e4466/e2568/index' ger.html [accessed 22.2.2011].

Knop S, Bauer K, Hebart H, Wandt H, Trümper L, Liebisch P, et al.A Randomized Comparison of TotalMarrow Irradiation, Busulfan and Cyclophosphamide with Tandem High-Dose Melphalan in Patients with Multiple Myeloma [\#728] [American Society of Hematology Annual meeting 2007 Atlanta, USA]. Blood. 110 2007; Vol. 110, issue 11:http://myeloma.org/ArticlePage.action?articleId= 2252 [accessed 22.2.2011].

GMMG-HD2 \{published and unpublished data\} Goldschmidt H. Single vs. double high-dose therapy in

First-line tandem high-dose chemotherapy and autologous stem cell transplantation versus single high-dose chemotherapy and 
multiple myeloma: second analysis of the GMMG-HD2 trial[PL8.02] [International Myeloma Workshop, Syndey 2005]. Haematologica. 90 2005; Vol. 90, issue s1:38 http://myeloma.org/pdfs/Sydney2005 'Goldschmidt 'P8.pdf [accessed 22.2.2011]

Goldschmidt H. Single vs double HDT in multiple myeloma [XIth International Myeloma Workshop, Kos 2007]. http: //myeloma.org/pdfs/Kos2007 Goldschmidt.pdf [accessed 22.2.2011].

Goldschmidt H. Neues aus den Studiengruppen - GMMG (German-Speaking Myeloma Multicenter Group) [2nd Heidelberg Myeloma Workshop 2009]. http://mdsforum.onkodin.de/myelom2009/content/e54/e8241/ e8264/index ' ger.html [accessed 22.2.2011].

Goldschmidt H. Single vs tandem autologous transplantation in multiple myeloma: the GMMG experience [IXth International Myeloma Foundation Workshop, Salamanca 2003]. Haematologica. 88 2003; Vol. 88, issue 4:S61.

\section{IFM94 \{published and unpublished data\}}

Attal M, Harousseau JL, Facon T, Guilhot F, Doyen C, Fuzibet JG, et al.Single versus double autologous stem-cell transplantation for multiple myeloma. New England Journal of Medicine 2003;349(26):2495-502.

Barlogie B, Attal M, Crowley J, van RF, Szymonifka J, Moreau P, et al.Long-term follow-up of autotransplantation trials for multiple myeloma: update of protocols conducted by the intergroupe francophone du myelome, southwest oncology group, and university of arkansas for medical sciences. Journal of Clinical Oncology 2010;28(7):1209-14.

\section{MAG95 \{published and unpublished data\}}

Fermand J, Alberti C, Marolleau J. High does therapy supported with autologous blood stem cell transplantation in multiple myeloma: long term follow-up of the prospective studies of the MAG group [PL 8.05] [Xth International Myeloma Foundation Workshop, Sydney 2005]. Haematologica http://myeloma.org/pdfs/ Sydney2005 'Fermand P8.pdf [accessed 22.2.2011]. Fermand JP, Marolleau JP, Alberti C, Divine M, Leblond V, Macro M, et al.American Society of Hematology, Orlando 2001 [In Single Versus Tandem High Dose Therapy (HDT) Supported with Autologous Blood Stem Cell (ABSC) Transplantation Using Unselected or CD34 Enriched ABSC: Preliminary results of a two by two designed randomized trial in 230 young patients with multiple myeloma (MM)]. Blood 2001;98 Suppl(11):815a. [: abstract: \#3387]

\section{N0265041749 \{unpublished data only\}}

Mahendra P. A randomised study of double versus single high dose therapy with autologous stem cell transplantation in newly diagnosed patients with Stage II/III multiple myeloma (N0265041749]. http://www.nihr.ac.uk/Profiles/ NRR.aspx?Publication ID=N0265041749 2001 [accessed 22.2.2011].

\section{References to studies excluded from this review}

\section{EBMTR \{published data only\}}

Morris C, Iacobelli S, Brand R, Bjorkstrand B, Drake $\mathrm{M}$, Niederwieser $\mathrm{D}$, et al.Benefit and timing of second transplantations in multiple myeloma: clinical findings and methodological limitations in a European Group for Blood and Marrow Transplantation registry study. Journal of Clinical Oncology 2004;22(9):1674-81.

Kim 2009 \{published data only\}

Kim SJ, Kim K, Kim BS, Jo DY, Kang HJ, Kim JS, et al.Clinical features and survival outcomes in patients with multiple myeloma: analysis of web-based data from the Korean Myeloma Registry. Acta Haematologica 2009;122 (4):200-10.

Koren 2010 \{published data only\}

Koren J, Spicka I, Straub J, Vackova B, Trnkova M, Pohlreich D, et al.Retrospective analysis of the results of high-dose chemotherapy with the support of autologous blood stem cells in patients with multiple myeloma. The experience of a single centre. Prague Medical Report 2010; 111(3):207-18.

\section{Lahuerta 2003 \{published data only\}}

Lahuerta JJ, Grande C, Martinez-Lopez J, De La SJ, Toscano $\mathrm{R}$, Ortiz MC, et al.Tandem transplants with different high-dose regimens improve the complete remission rates in multiple myeloma. Results of a Grupo Espanol de Sindromes Linfoproliferativos/Trasplante Autologo de Medula Osea phase II trial. British Journal of Haematology 2003;120(2):296-303

\section{NMSG \{published data only\}}

Bjorkstrand B, Klausen TW, Remes K, Gruber A, Knudsen LM, Bergmann OJ, et al.Double versus single highdose melphalan $200 \mathrm{mg} / \mathrm{m}^{2}$ and autologous stem cell transplantation for multiple myeloma: a region-based study in 484 patients from the Nordic area. Hematology Reviews. 1 2009; Vol. 1:e2.

Sonneveld 2007 \{published data only\}

Sonneveld P, van der HB, Segeren CM, Vellenga E, Croockewit AJ, Verhoe GE, et al.Intermediate-dose melphalan compared with myeloablative treatment in multiple myeloma: long-term follow-up of the Dutch Cooperative Group HOVON 24 trial. Haematologica 2007; 92(7):928-35.

\section{Total therapy \{published data only\}}

Barlogie B, Anaissie E, van RF, Shaughnessy JD Jr, Szymonifka J, et al.Reiterative survival analyses of Total Therapy 2 for multiple myeloma elucidate follow-up time dependency of prognostic variables and treatment arms. Journal of Clinical Oncology 2010;28(18):3023-7.

Barlogie B, Jagannath S, Desikan KR, Mattox S, Vesole D, Siegel D, et al.Total therapy with tandem transplants for newly diagnosed multiple myeloma. Blood 1999;93(1): $55-65$.

Barlogie B, Jagannath S, Vesole DH, Naucke S, Cheson B, Mattox $S$, et al.Superiority of tandem autologous

First-line tandem high-dose chemotherapy and autologous stem cell transplantation versus single high-dose chemotherapy and 
transplantation over standard therapy for previously untreated multiple myeloma. Blood 1997;89(3):789-93. Barlogie B, Shaughnessy J, Anaissie E, van Rhee F, Alsayed Y, Waheed S, et al.Modeling for Cure:Total Therapy Trials for Newly Diagnosed Multiple Myeloma: Let the Math Speak! [American Society of Hematology - Annual meeting held in New Orleans December 5-8, 2009]. http:/ /myeloma.uams.edu/Modeling-for-Cure-ASH-2009.pdf [accessed 01.03.2011].

Barlogie B, Tricot G, Rasmussen E, Anaissie E, van Rhee F, Zangari M, et al.Total therapy 2 without thalidomide in comparison with total therapy 1: role of intensified induction and posttransplantation consolidation therapies. Blood 2006;107(7):2633-8.

Barlogie B, Tricot GJ, van Rhee F, Angtuaco E, Walker $\mathrm{R}$, Epstein J, et al.Long-term outcome results of the first tandem autotransplant trial for multiple myeloma. British Journal of Haematology 2006;135(2):158-64.

Barlogie B, Zangari M, Bolejack V, Hollmig K, Anaissie E, van Rhee F, et al.Superior 12-year survival after at least 4year continuous remission with tandem transplantations for multiple myeloma. British Journal of Haematology 2006;6 (6):469-74.

\section{References to ongoing studies}

\section{NCT01109004 \{published data only\}}

Horowitz. Stem Cell Transplant With Lenalidomide Maintenance in Patients With Multiple Myeloma (BMT CTN 0702; NCT01109004). http://clinicaltrials.gov/ct2/ show/NCT01109004?term=NCT01109004\&rank=1 2010 [accessed 22.2.2011].

\section{Additional references}

\section{Abdelkefi 2008}

Abdelkefi A, Ladeb S, Torjman L, Othman TB, Lakhal

A, Romdhane NB, et al.Single autologous stem-cell transplantation followed by maintenance therapy with thalidomide is superior to double autologous transplantation in multiple myeloma: results of a multicenter randomized clinical trial. Blood 2008;111(4):1805-10.

\section{Abdelkefi 2009}

Abdelkefi A, Ladeb S, Torjman L, Ben Othman T, Lakhal A, Ben Romdhane N, et al.on behalf of the Tunisian Multiple Myeloma Study Group. Retraction of Abdelkefi A, Ladeb S, Torjman L, Othman TB, Lakhal A, Romdhane NB, et al. Blood 2008 Feb 15;111(4):1805-10; PM. Blood 2009;113 (24): 6265 .

Alexander 2007

Alexander DD, Mink PJ, Adami HO, Cole P, Mandel JS, Oken MM, et al.Multiple myeloma: a review of the epidemiologic literature. International Journal of Cancer 2007;120 Suppl 12:40-61.

Anderson 2008

Anderson KC, Kyle RA, Rajkumar SV, Stewart AK, Weber D, Richardson P. Clinically relevant end points and new drug approvals for myeloma. Leukemia 2008;22(2):231-9.

\section{Attal 1996}

Attal M, Harousseau JL, Stoppa AM, Sotto JJ, Fuzibet JG, Rossi JF, et al.A prospective, randomized trial of autologous bone marrow transplantation and chemotherapy in multiple myeloma. Intergroupe Francais du Myelome. New England Journal of Medicine 1996;335(2):91-7.

\section{Attal 2007}

Attal M, Moreau P, Avet-Loiseau H, Harousseau JL. Stem cell transplantation in multiple myeloma. Hematology American Society of Hematology Education Program 2007: 311-6.

\section{Attal 2009}

Attal M, Harousseau JL. The role of high-dose therapy with autologous stem cell support in the era of novel agents. Seminars in Hematology 2009;46(2):127-32.

\section{Awedan 2002}

Awedan AA. High intensity regimens with autologous hematopoietic stem cell transplantation as treatment of multiple myeloma. Annals of Transplantation 2002;7(2): $38-43$.

\section{Barlogie 1986}

Barlogie B, Hall R, Zander A, Dicke K, Alexanian R. High-dose melphalan with autologous bone marrow transplantation for multiple myeloma. Blood 1986;67(5): 1298-301.

\section{Barlogie 1997}

Barlogie B, Jagannath S, Vesole DH, Naucke S, Cheson B, Mattox S, et al.Superiority of tandem autologous transplantation over standard therapy for previously untreated multiple myeloma. Blood 1997;89(3):789-93.

\section{Barlogie 2006}

Barlogie B, Tricot G, Rasmussen E, Anaissie E, van Rhee F, Zangari M, et al.Total therapy 2 without thalidomide in comparison with total therapy 1: role of intensified induction and posttransplantation consolidation therapies. Blood 2006;107(7):2633-8.

\section{Barlogie 2007}

Barlogie B, van Rhee F, Anaissie E, Epstein J, Crowley J, Shaughnessy J. Should autologous transplant be part of the primary treatment in MM?. Haematologica. 92 2007; Vol. 92 Suppl 2:67.

\section{Barlogie 2009}

Barlogie B, Shaughnessy J, Anaissie E, van Rhee F, Alsayed Y, Waheed S, et al.Modeling for Cure:Total Therapy Trials for Newly Diagnosed Multiple Myeloma: Let the Math Speak!. American Society of Hematology - Annual meeting held in New Orleans December 5-8, 2009.

\section{Bladé 1998}

Blade J, Samson D, Reece D, Apperley J, Bjorkstrand B, Gahrton G, et al.Criteria for evaluating disease response and progression in patients with multiple myeloma treated by high-dose therapy and haemopoietic stem cell transplantation. Myeloma Subcommittee of the EBMT. European Group for Blood and Marrow Transplant. British Journal of Haematology 1998;102(5):1115-23.

First-line tandem high-dose chemotherapy and autologous stem cell transplantation versus single high-dose chemotherapy and 


\section{Blair 2004}

Blair E. Gold is not always good enough: the shortcomings of randomization when evaluating interventions in small heterogeneous samples. Journal of Clinical Epidemiology 2004;57(12):1219-22.

\section{Campagnaro 2008}

Campagnaro E, Saliba R, Giralt S, Roden L, Mendoza F, Aleman A, et al.Symptom burden after autologous stem cell transplantation for multiple myeloma. Cancer 2008;112 (7):1617-24

\section{Cavo 2010}

Cavo M, Tacchetti P, Patriarca F, Petrucci MT, Pantani L, Galli M, et al.Bortezomib with thalidomide plus dexamethasone compared with thalidomide plus dexamethasone as induction therapy before, and consolidation therapy after, double autologous stem-cell transplantation in newly diagnosed multiple myeloma: a randomised phase 3 study. Lancet 2010;376(9758): 2075-85.

Chalmers 2009

Chalmers I, Glasziou P. Avoidable waste in the production and reporting of research evidence. Lancet 2009;374(9683): 86-9.

\section{CHMP/EWP/27994/08 2008}

CHMP/EWP/27994/08. Appendix 1 to the Guideline on the Evaluation of Anticancer Medicinal Products in Man Methodological Considerations for Using Progression-Free Survival (PFS) as Primary endpoints in confirmatory trials for registration. http://www.ema.europa.eu/pdfs/human/ ewp/2799408en.pdf 2008 [accessed 22.2.2011].

\section{Clarke 2004}

Clarke M. Doing new research? Don't forget the old. PLoS Medicine 2004;1(2):e35.

\section{Copelan 2006}

Copelan EA. Hematopoietic stem-cell transplantation. New England Journal of Medicine 2006;354(17):1813-26.

\section{CPMP/EWP/205/95 2005}

CPMP/EWP/205/95 Rev.3. Evaluation of Anticancer Medicinal Products in Man. http://www.ema.europa.eu/ docs/en 'GB/document ' library/Scientific' guideline/2009/ 12/WC500017748.pdf 2005 [accessed 22.2.2011].

\section{Curt 2008}

Curt GA, Chabner BA. One in five cancer clinical trials is published: a terrible symptom--what's the diagnosis? Oncologist 2008;13(9):923-4.

\section{Dickersin 1994}

Dickersin K, Scherer R, Lefebvre C. Identifying relevant studies for systematic reviews. [Identifying relevant studies for systematic reviews.]. British Medical Journal 1994;309 (6964):1286-91. [MEDLINE: 7718048]

\section{Durie 1975}

Durie BG, Salmon SE. A clinical staging system for multiple myeloma. Correlation of measured myeloma cell mass with presenting clinical features, response to treatment, and survival. Cancer 1975;36(3):842-54.

\section{Durie 2001}

Durie BG. The epidemiology of multiple myeloma.

Seminars in Hematology 2001;38 Suppl 3(2):1-5.

\section{Durie 2006}

Durie BG, Harousseau JL, Miguel JS, Blade J, Barlogie B, Anderson $\mathrm{K}$, et al.International uniform response criteria for multiple myeloma. Leukemia 2006;20(9):1467-73.

Durie 2008

Durie BG. Treatment of myeloma--are we making progress? . New England Journal of Medicine 2008;359(9):964-6.

\section{Durie 2010}

Durie BG. Role of new treatment approaches in defining treatment goals in multiple myeloma--the ultimate goal is extended survival. Cancer Treatment Reviews 2010;36 Suppl 2:18-23.

Egger 2001

Egger M, Smith GD, Sterne JA. Uses and abuses of metaanalysis. Clinical Medicine 2001;1(6):478-84.

Einsele 2007

Einsele H. Stem Cell Transplantation for MM: Analysis of Prognostic Factors[S9.3]. Haematologica XIth International Myeloma Foundation Workshop, Kos. 902007 http: //myeloma.org/pdfs/Kos2007 Einsele.pdf [accessed 22.2.2011]; Vol. 90, issue s2:49.

\section{EMA/CHMP/EWP/520088/2008}

Effficacy working party of the European Medical Agencies. Appendix 2 to the Guideline on the evaluation of Anticancer Medicinal Products in Man (CPMP/EWP/205/95 Rev. 3) on Confirmatory studies in Haematological. http:// www.ema.europa.eu/pdfs/human/ewp/52008808enfin.pdf 2010 [accessed 22.2.2011].

\section{Feinstein 1995}

Feinstein AR. Meta-analysis: statistical alchemy for the $21 \mathrm{~s}$ century. Journal of Clinical Epidemiology 1995;48(1):71-9.

\section{Fermand 2007}

Fermand JP. Should autologous transplant be part of the primary treatment in MM? [XIth International Myeloma Workshop, Kos 2007]. Haematologica. 92 2007; Vol. 92, issue s2:68-9 http://myeloma.org/pdfs/ Kos2007 Fermand.pdf [accessed 22.2.2011].

\section{Fonseca 2007}

Fonseca R, Stewart AK. Targeted therapeutics for multiple myeloma: the arrival of a risk-stratified approach. Molecular Cancer Therapy 2007;6(3):802-10.

\section{Fonseca 2009}

Fonseca R, Bergsagel PL, Drach J, Shaughnessy J, Gutierrez N, Stewart AK, et al.International Myeloma Working Group molecular classification of multiple myeloma: spotlight review. Leukemia 2009;23(12):2210-21.

Gertz 2007

Gertz MA. Relevant prognostic features of multiple myeloma and the new International Staging System. Leukemia \& Lymphoma 2007;48(3):458-68.

First-line tandem high-dose chemotherapy and autologous stem cell transplantation versus single high-dose chemotherapy and 
Gertz 2008

Gertz MA, Ansell SM, Dingli D, Dispenzieri A, Buadi FK, Elliott MA, et al.Autologous stem cell transplant in 716 patients with multiple myeloma: low treatment-related mortality, feasibility of outpatient transplant, and effect of a multidisciplinary quality initiative. Mayo Clinical Proceedings 2008;83(10):1131-8.

\section{Gertz 2009}

Gertz M. Is autologous stem cell transplantation the therapy of choice for the treatment of Multiple Myeloma patients? CONTRA. 2nd Heidelberg Myeloma Workshop 2009 http://mds-forum.onkodin.de/myelom2009/content/e54/ e8239/e8258/index' ger.html [accessed 22.2.2011].

\section{Giralt 2009}

Giralt S, Vesole DH, Somlo G, Krishnan A, Stadtmauer E, Mccarthy P, et al.Re: Tandem vs single autologous hematopoietic cell transplantation for the treatment of multiple myeloma: a systematic review and meta-analysis. Journal of the National Cancer Institute 2009;101(13): 964-7.

\section{Giralt 2010}

Giralt S. $200 \mathrm{mg} / \mathrm{m}$ (2) melphalan--the gold standard for multiple myeloma. Nature Reviews Clinical Oncology 2010; 7(9):490-1.

\section{GMMG-HD5}

Goldschmidt 2009. The GMMG-HD5 trial: bortezomibbased induction prior to high dose therapy and autologous stem cell transplantation followed by lenalidomide-based consolidation and maintenance therapy in patients with multiple myeloma. http://www.controlled-trials.com/ ISRCTN05745813 [accessed 26 May 2011] 2009.

\section{Gratwohl 2007}

Gratwohl A. Activity survey and historical perspective of autologous stem cell transplantation in Europe. Seminars in Hematology 2007;44(4):220-6.

\section{Greipp 2005}

Greipp PR, San Miguel J, Durie BG, Crowley JJ, Barlogie $\mathrm{B}$, Blade J, et al.International staging system for multiple myeloma. Journal Clinical Oncology 2005;23(15):3412-20.

\section{Hahn 2003}

Hahn T, Wingard JR, Anderson KC, Bensinger WI, Berenson JR, Brozeit G, et al.The role of cytotoxic therapy with hematopoietic stem cell transplantation in the therapy of multiple myeloma: an evidence-based review. Biology of Blood and Marrow Transplantation 2003;9(1):4-37.

\section{Harousseau 1992}

Harousseau JL, Milpied N, Laporte JP, Collombat P, Facon $\mathrm{T}$, Tigaud JD, et al.Double-intensive therapy in high-risk multiple myeloma. Blood 1992;79(11):2827-33.

Harousseau 2009

Harousseau JL, Attal M, vet-Loiseau H. The role of complete response in multiple myeloma. Blood 2009;114 (15):3139-46.

\section{Harousseau 2009a}

Harousseau JL, Moreau P. Autologous hematopoietic stemcell transplantation for multiple myeloma. New England Journal of Medicine 2009;360(25):2645-54.

\section{Higgins 2011}

Cochrane Handbook. Cochrane Handbook for Systematic Reviews of Interventions [version 5.1.0.]. The Cochrane Collaboration, 2011.

\section{Hopewell 2009}

Hopewell S, Loudon K, Clarke MJ, Oxman AD, Dickersin K. Publication bias in clinical trials due to statistical significance or direction of trial results. Cochrane Database of Systematic Reviews 2009, (1):MR000006.

Hopewell 2010

Hopewell S, Dutton S, Yu L-M, Chan A-W, Altman DG. The quality of reports of randomised trials in 2000 and 2006: comparative study of articles indexed in PubMed. BMJ. 340 2010; Vol. 340.

\section{International Myeloma Workshop 2003} International Myeloma Working group. Criteria for the classification of monoclonal gammopathies, multiple myeloma and related disorders: a report of the International Myeloma Working Group. British Journal of Haematology 2003;121(5):749-57.

\section{IQWIG N05-03C}

Institut für Qualität und Wirtschaftlichkeit im Gesundheitswesen (editor). Stem cell transplantation in multiple myeloma [Stammzelltransplantation beim multiplen Myelom]. https://www.iqwig.de/download/N0503C'Vorbericht 'Stammzelltransplantation 'bei' Multiplem 'Myelom.pdf 2011.

\section{Jantunen 2006}

Jantunen E, Itala M, Siitonen T, Koivunen E, Leppa S, Juvonen E, et al.Late non-relapse mortality among adult autologous stem cell transplant recipients: a nation-wide analysis of 1,482 patients transplanted in 1990-2003. European Journal of Haematology 2006;77(2):114-9.

\section{Jantunen 2006a}

Jantunen E, Itala M, Lehtinen T, Kuittinen O, Koivunen E, Leppa S, et al.Early treatment-related mortality in adult autologous stem cell transplant recipients: a nation-wide survey of 1482 transplanted patients. European Journal of Haematology 2006;76(3):245-50.

\section{Johnsen 2010}

Johnsen HE, Klausen TW, Boegsted M, Lenhoff S, Gimsing P, Christiansen I, et al.Improved survival for multiple myeloma in denmark based on autologous stem cell transplantation and novel drug therapy in collaborative trials: analysis of accrual, prognostic variables, selection bias, and clinical behavior on survival in more than 1200 patients in trials of the nordic myeloma study group. Clinical Lymphoma Myeloma and Leukemia 2010;10(4):290-6.

Jones 2008

Jones JA, Qazilbash MH, Shih YC, Cantor SB, Cooksley CD, Elting LS. In-hospital complications of autologous

First-line tandem high-dose chemotherapy and autologous stem cell transplantation versus single high-dose chemotherapy and 
hematopoietic stem cell transplantation for lymphoid malignancies: clinical and economic outcomes from the Nationwide Inpatient Sample. Cancer 2008;112(5): 1096-105.

\section{Juni 2001}

Juni P, Altman DG, Egger M. Systematic reviews in health care: Assessing the quality of controlled clinical trials. BMJ 2001;323(7303):42-6.

\section{Keirns 2008}

Keirns CC, Carr BG. From the emergency department to vital statistics: cause of death uncertain. Academic Emergency Medicine 2008;15(8):768-75.

\section{Klein-Geltink 2007}

Klein-Geltink JE, Rochon PA, Dyer S, Laxer M, Anderson GM. Readers should systematically assess methods used to identify, measure and analyze confounding in observational cohort studies. Journal of Clinical Epidemiology 2007;60(8): 766-72.

\section{Klungel 2004}

Klungel OH, Martens EP, Psaty BM, Grobbee DE, Sullivan $\mathrm{SD}$, Stricker $\mathrm{BH}$, et al.Methods to assess intended effects of drug treatment in observational studies are reviewed. Journal of Clinical Epidemiology 2004;57(12):1223-31.

\section{Koreth 2007}

Koreth J, Cutler CS, Djulbegovic B, Behl R, Schlossman RL, Munshi NC, et al.High-dose therapy with single autologous transplantation versus chemotherapy for newly diagnosed multiple myeloma: A systematic review and meta-analysis of randomized controlled trials. Biololgy of Blood and Marrow Transplantation 2007;13(2):183-96.

\section{Kortüm 2010}

Kortüm M, Einsele H, Naumann R, Peest D, Liebisch P, Goldschmidt H. Leitlinie Multiples Myelom. http:// www.dgho.de/onkopedia/Multiples\%20Myelom [accessed 26.05.11] 2010.

\section{Krzyzanowska 2003}

Krzyzanowska MK, Pintilie M, Tannock IF. Factors associated with failure to publish large randomized trials presented at an oncology meeting. JAMA 2003;290(4): 495-501.

\section{Kumar 2008}

Kumar SK, Rajkumar SV, Dispenzieri A, Lacy MQ, Hayman SR, Buadi FK, et al.Improved survival in multiple myeloma and the impact of novel therapies. Blood 2008; 111(5):2516-20.

\section{Kumar 2009}

Kumar A, Kharfan-Dabaja MA, Glasmacher A, Djulbegovic B. Tandem versus single autologous hematopoietic cell transplantation for the treatment of multiple myeloma: a systematic review and meta-analysis. Journal of the National Cancer Institute 2009;101(2):100-6.

\section{Kumar 2009a}

Kumar A, Djulbegovic B. Author reply to Giralt et al and Tricot et al: Tandem versus single autologous hematopoietic cell transplantation for the treatment of multiple myeloma: a systematic review and meta-analysis. Journal of the
National Cancer Institute. 101 2009; Vol. 101, issue 13: 966-7.

\section{Kumar 2009b}

Kumar A, Djulbegovic B. Author reply to Mehta: Re: Tandem versus single autologous hematopoietic cell transplantation for the treatment of multiple myeloma: a systematic review and meta-analysis. Journal of the National Cancer Institute. 101 2009; Vol. 101, issue 20:1431-3.

\section{Kunz 1998}

Kunz R, Oxman AD. The unpredictability paradox: review of empirical comparisons of randomised and nonrandomised clinical trials. BMJ 1998;317(7167):1185-90.

\section{Lahuerta 2010}

Lahuerta JJ, Mateos MV, Martínez-López J, Grande C, de la Rubia J, Rosiñol L, et al.Grupo Español de MM and Programa para el Estudio de la Terapéutica en Hemopatía Maligna Cooperative Study Groups. Busulfan $12 \mathrm{mg} / \mathrm{kg}$ plus melphalan $140 \mathrm{mg} / \mathrm{m} 2$ versus melphalan $200 \mathrm{mg} / \mathrm{m} 2$ as conditioning regimens for autologous transplantation in newly diagnosed multiple myeloma patients included in the PETHEMA/GEM2000 study. Haematologica 2010;95(11): 1913-20.

\section{Lane 2005}

Lane SW, Gill D, Mollee PN, Rajkumar SV. Role of VAD in the initial treatment of multiple myeloma. Blood 2005; 106(10):3674-5.

\section{Laubach 2011}

Laubach J, Richardson P, Anderson K. Multiple myeloma. Annual Review of Medicine 2011;62:249-64.

Levy 2005

Levy V, Katsahian S, Fermand JP, Mary JY, Chevret S. A meta-analysis on data from 575 patients with multiple myeloma randomly assigned to either high-dose therapy or conventional therapy. Medicine (Baltimore) 2005;84(4): 250-60.

Majhail 2008

Majhail NS. Old and new cancers after hematopoietic-cell transplantation. Hematology American Society of Hematology Education Program 2008:142-9.

\section{Mehta 2009}

Mehta J. Re: Tandem vs single autologous hematopoietic cell transplantation for the treatment of multiple myeloma: a systematic review and meta-analysis. Journal of the National Cancer Institute 2009;101(20):1430-1.

\section{Moher 2001}

Moher D, Schulz KF, Altman D. The CONSORT statement: revised recommendations for improving the quality of reports of parallel-group randomized trials.. JAMA 2001;285(15):1987-91.

\section{Moher 2009}

Moher D, Liberati A, Tetzlaff J, Altman DG. Preferred reporting items for systematic reviews and meta-analyses: the PRISMA statement. Journal of Clinical Epidemiology 2009;62(10):1006-12.

First-line tandem high-dose chemotherapy and autologous stem cell transplantation versus single high-dose chemotherapy and 


\section{Moore 1998}

Moore RA, Gavaghan D, Tramer MR, Collins SL, McQuay HJ. Size is everything--large amounts of information are needed to overcome random effects in estimating direction and magnitude of treatment effects. Pain 1998;78(3): 209-16.

Moreau 2002

Moreau P, Facon T, Attal M, Hulin C, Michallet M, Maloisel F, et al.Comparison of $200 \mathrm{mg} / \mathrm{m}(2)$ melphalan and 8 Gy total body irradiation plus $140 \mathrm{mg} / \mathrm{m}(2)$ melphalan as conditioning regimens for peripheral blood stem cell transplantation in patients with newly diagnosed multiple myeloma: final analysis of the Intergroupe Francophone du Myelome 9502 randomized trial. Blood 2002;99(3):731-5.

\section{Moreau 2011}

Moreau P, Attal M, Pegourie B, Planche L, Hulin C, Facon $\mathrm{T}$, et al.Achievement of VGPR to induction therapy is an important prognostic factor for longer PFS in the IFM 2005-01 trial. Blood 2011;117(11):3041-4.

\section{Morris 2004}

Morris C, Iacobelli S, Brand R, Bjorkstrand B, Drake $\mathrm{M}$, Niederwieser $\mathrm{D}$, et al.Benefit and timing of second transplantations in multiple myeloma: clinical findings and methodological limitations in a European Group for Blood and Marrow Transplantation registry study. Journal of Clinical Oncology 2004;22(9):1674-81.

\section{Munshi 2008}

Munshi NC. Plasma cell disorders: an historical perspective. Hematology American Society of Hematology Education Program 2008:297.

\section{Munshi 2011}

Munshi NC, Anderson KC, Bergsagel PL, Shaughnessy J, Palumbo A, Durie B, et al.Consensus recommendations for risk stratification in multiple myeloma: report of the International Myeloma Workshop Consensus Panel 2. Blood 2011;117(18):4696-700.

\section{Myeloma Trialists 98}

Myeloma Trialists' Collaborative Group. Combination chemotherapy versus melphalan plus prednisone as treatment for multiple myeloma: an overview of 6,633 patients from 27 randomized trials. Myeloma Trialists' Collaborative Group. Journal of Clinical Oncology 1998;16 (12):3832-42.

\section{Nahi 2011}

Nahi H, Sutlu T, Jansson M, Alici E, Gahrton G. Clinical impact of chromosomal aberrations in multiple myeloma. Journal of Internal Medicine 2011;269(2):137-47.

\section{NCCN 2011}

NCCN Multiple Myeloma Panel. Multiple Myeloma, Version 3.2010. NCCN Clinical pratice guidelines in Oncology 2011; Vol. http://guidelines.nccn.org/ published-guideline/AB9CB2A2-ABDF-9C66-6D928F8FD1F26358/guideline.pdf [accessed 01.03.2011].
Pignon 2001

Pignon JP, Hill C. Meta-analyses of randomised clinical trials in oncology. Lancet Oncology 2001;2(8):475-82.

\section{Podar 2009}

Podar K, Chauhan D, Anderson KC. Bone marrow microenvironment and the identification of new targets for myeloma therapy. Leukemia 2009;23(1):10-24.

\section{Rajkumar 2008}

Rajkumar SV. Treatment of myeloma: cure vs control. Mayo Clinical Proceedings 2008;83(10):1142-5.

Ramsey 2008

Ramsey S, Scoggins J. Commentary: practicing on the tip of an information iceberg? Evidence of underpublication of registered clinical trials in oncology. Oncologist 2008;13(9): 925-9.

\section{Schulz 2002}

Schulz KF, Grimes DA. Sample size slippages in randomised trials: exclusions and the lost and wayward. Lancet 2002; 359(9308):781-5.

\section{Tam 2008}

Tam VC, Hotte SJ. Consistency of phase III clinical trial abstracts presented at an annual meeting of the American Society of Clinical Oncology compared with their subsequent full-text publications. Journal of Clinical Oncology 2008;26(13):2205-11.

\section{Tricot 2008}

Tricot G. Is more better in myeloma?. Blood 2008;112(9): 3532.

\section{Tricot 2009}

Tricot G, Kern SE, Barlogie B. Re: Tandem vs single autologous hematopoietic cell transplantation for the treatment of multiple myeloma: a systematic review and meta-analysis. Journal of the National Cancer Institute 2009; 101(13):964-6.

\section{Turesson 2010}

Turesson I, Velez R, Kristinsson SY, Landgren O. Patterns of improved survival in patients with multiple myeloma in the twenty-first century: a population-based study. Journal of Clinical Oncology 2010;28(5):830-4.

Vandenbroucke 2008

Vandenbroucke JP. Observational research, randomised trials, and two views of medical science. PLoS Medicine 2008;5(3):e67.

von Elm 2008

von Elm E, Altman DG, Egger M, Pocock SJ, Gotzsche PC, Vandenbroucke JP. The Strengthening the Reporting of Observational Studies in Epidemiology (STROBE) statement: guidelines for reporting observational studies. Journal of Clinical Epidemiology 2008;61(4):344-9.

Wheatley 2006

Wheatley K, Hills RK, Burnett AK. Problems with up-front randomization in clinical trials. Journal of Clinical Oncology 2006;24(34):5471-2. 
Wilson 2003

Wilson RL, Gray ML, Giralt S. Barriers to second transplant for multiple myeloma in a randomised autologous tandem trial. Biology of Blood and Marrow Transplantation IBMTR/ABMTR Participants' meeting, Keystone

Colorado, January 2003.. 9 2003; Vol. 9, issue 2.

* Indicates the major publication for the study 
CHARACTERISTICS OF STUDIES

\section{Characteristics of included studies [ordered by study ID]}

Bologna96

\begin{tabular}{ll}
\hline Methods & $\begin{array}{l}\text { Central randomisation before induction treatment } \\
\text { Multicentre }(\mathrm{N}=32) \text { RCT addressing superiority of TASCT }\end{array}$ \\
\hline Participants & $\begin{array}{l}\text { TASCT } \mathrm{N}=158, \text { SASCT N }=163 \\
\text { age }<60 \text { years } \\
\text { Previously untreated, symptomatic or progressive MM Salmon-Durie stage I-III } \\
\text { (Baseline characteristics Table } 2)\end{array}$ \\
\hline Interventions & $\begin{array}{l}1 \mathrm{x} 200 \mathrm{mg} / \mathrm{m}^{2} \text { melphalan }+\left(140 \mathrm{mg} / \mathrm{m}^{2} \text { melphalan }+12 \mathrm{mg} / \mathrm{m}^{2} \text { oral busulfan) vs } 1 \mathrm{x}\right. \\
\text { 200 mg/m } \mathrm{m}^{2} \text { melphalan SASCT } \\
\text { (Treatment regimen Table 3) }\end{array}$ \\
\hline Outcomes & $\begin{array}{l}\text { OS, EFS, transplantation-related mortality in ITT population } \\
\text { (Definition of endpoints Table 4; Table 5) }\end{array}$ \\
\hline Notes & $\begin{array}{l}\text { Journal publication (peer-review) } \\
\text { Null-bias (only } 65 \% \text { compliance with } 2 \mathrm{nd} \text { ASCT) } \\
\text { Potential confounding by subsequent treatment (superior post-relapse survival for } \\
\text { SASCT arm) }\end{array}$ \\
\hline
\end{tabular}

\section{Risk of bias}

\begin{tabular}{|c|c|c|}
\hline Bias & Authors' judgement & Support for judgement \\
\hline $\begin{array}{l}\text { Random sequence generation (selection } \\
\text { bias) }\end{array}$ & Low risk & Central \\
\hline Allocation concealment (selection bias) & Unclear risk & Central \\
\hline $\begin{array}{l}\text { Blinding (performance bias and detection } \\
\text { bias) } \\
\text { All outcomes }\end{array}$ & High risk & $\begin{array}{l}\text { Unavoidable in view of obvious difference } \\
\text { in treatment plan }\end{array}$ \\
\hline Other bias & High risk & See Table 6 and Figure 2 \\
\hline
\end{tabular}

\section{DM00-196}

Methods

Randomised phase II trial, no information on method of randomisation

Single centre study comparing without reporting of basic statistical assumption (superiority/non-inferiority) 


\begin{tabular}{|c|c|c|}
\hline Participants & \multicolumn{2}{|c|}{$\begin{array}{l}\text { Patients of MM not achieving CR by day } 180 \text { after initial ASCT (planned for initial } \\
\text { ASCT N=120; interim analysis on } \mathrm{N}=31 \text { at } \mathrm{d} 180 \text { post transplantation) } \\
\text { No further information on age or stage }\end{array}$} \\
\hline Interventions & \multicolumn{2}{|c|}{$\begin{array}{l}\text { TASCT (1. ASCT: "high dose melphalan"; } 2 \text {. ASCT: melphalan/topotecan/cyclophos- } \\
\text { phamide) vs SASCT versus maintenance with thalidomide/dexamethasone }\end{array}$} \\
\hline Outcomes & \multicolumn{2}{|c|}{ PR and CR, relative toxicities } \\
\hline Notes & \multicolumn{2}{|c|}{$\begin{array}{l}\text { Register information; no clinical outcome data for systematic review reported } \\
\text { Steep decrease of compliance with second ASCT (high refusal rate by patients to proceed } \\
\text { to second transplantation, developing contra-indications, denied coverage by insurance) }\end{array}$} \\
\hline \multicolumn{3}{|l|}{ Risk of bias } \\
\hline Bias & Authors' judgement & Support for judgement \\
\hline $\begin{array}{l}\text { Random sequence generation (selection } \\
\text { bias) }\end{array}$ & Unclear risk & NR \\
\hline Allocation concealment (selection bias) & Unclear risk & NR \\
\hline $\begin{array}{l}\text { Blinding (performance bias and detection } \\
\text { bias) } \\
\text { All outcomes }\end{array}$ & Unclear risk & NR \\
\hline Other bias & Unclear risk & NR \\
\hline
\end{tabular}

\section{DSMM-I}

\begin{tabular}{ll} 
Methods & $\begin{array}{l}\text { Randomisation of patients with at least stable disease after induction and successful stem- } \\
\text { cell mobilisation } \\
\text { Multicentre }(\mathrm{N}=46-49) \text { RCT addressing superiority of experimental SASCT regimen } \\
\text { compared to trial; TASCT }\end{array}$ \\
\hline Participants & $\begin{array}{l}\text { TASCT N=98; SASCT N=100 } \\
\text { 660 years; }\end{array}$ \\
\hline $\begin{array}{l}\text { de novo or max. }<6 \text { cycles of “conventional Ctx" } \\
\text { Salmon-Durie stage II and III } \\
\text { (Baseline characteristics Table 2) }\end{array}$ \\
\hline Interventions & $\begin{array}{l}2 \times 200 \text { mg/m² melphalan TASCT compared to experimental SASCT (chemo-radio } \\
\text { conditioning regimen) } \\
\text { (Treatment plan Table 3) }\end{array}$ \\
\hline Outcomes & $\begin{array}{l}\text { OS, EFS (primary endpoint), so-called TRM } \\
\text { (Definitions of endpoints Table 4; Table 5) }\end{array}$ \\
\hline
\end{tabular}




\begin{tabular}{l|ll}
\hline Notes & $\begin{array}{l}\text { Conference presentations with some inconsistencies } \\
\text { Safety population differs notably from ITT population (TASCT N=118; SASCT N= } \\
80)\end{array}$ & $\begin{array}{l}\text { Data likely immature } \\
\text { Total follow-up of only 48-61 months according to Kaplan-Meier graph (reported as } \\
\text { median follow-up) } \\
\text { Potential confounding by cross-over from SASCT to TASCT in 18\% of patients and by } \\
\text { subsequent treatment }\end{array}$ \\
\hline Risk of bias & Authors' judgement & Support for judgement \\
\hline Bias & Unclear risk & NR \\
\hline $\begin{array}{l}\text { Random sequence generation (selection } \\
\text { bias) }\end{array}$ & Unclear risk & NR \\
\hline Allocation concealment (selection bias) & High risk & $\begin{array}{l}\text { Unavoidable in view of obvious difference } \\
\text { in treatment plan }\end{array}$ \\
\hline $\begin{array}{l}\text { Blinding (performance bias and detection } \\
\text { bias) } \\
\text { All outcomes }\end{array}$ & High risk & See Table 6 and Figure 2 \\
\hline \begin{tabular}{l} 
Other bias \\
\hline
\end{tabular} & &
\end{tabular}

\section{GMMG-HD2}

\begin{tabular}{ll} 
Methods & $\begin{array}{l}\text { Randomisation of patients with at least stable disease after induction } \\
\text { Multicentre (N=66) RCT comparing TASCT with SASCT without reporting of aim } \\
\text { (superiority/non-inferiority) } \\
\text { Optional additional randomisation of induction regimen (VID vs VAD) }\end{array}$ \\
\hline Participants & $\begin{array}{l}\text { TASCT N } 180 \text {; SASCT N=178 (evaluated patients; actual number of patients depend- } \\
\text { ing unclear and different in different conference presentations (N=358-485) } \\
\text { age } 18 \text { - 66 years } \\
\text { previously untreated (or max } 6 \text { cycles of conventional chemotherapy) patients with MM } \\
\text { Salmon-Durie stage II and III } \\
\text { (Baseline characteristics Table 2) }\end{array}$ \\
\hline Interventions & $\begin{array}{l}2 \times 200 \text { mg/m² melphalan TASCT vs } 1 \times \text { x 200 mg/m² melphalan SASCT (Treatment } \\
\text { plan Table 3) }\end{array}$ \\
\hline Outcomes & $\begin{array}{l}\text { OS, EFS (primary endpoint), so-called TRM (ITT and PP analyses) } \\
\text { (Definitions of endpoints Table 4; Table 5) }\end{array}$ \\
\hline Notes & $\begin{array}{l}\text { Conference presentation with some inconsistencies } \\
\text { Unclear, how the two randomisations were analysed (separately?, interaction test?) } \\
\text { Very low compliance (52\% of evaluable population) with 2nd ASCT (null bias for OS, } \\
\text { EFS); }\end{array}$ \\
\hline
\end{tabular}


GMMG-HD2 (Continued)

Potential confounding by salvage treatment (OS)

Numerically inferior OS for TASCT group in PP analysis

\section{Risk of bias}

\begin{tabular}{l|ll}
\hline Bias & Authors' judgement & Support for judgement \\
\hline $\begin{array}{l}\text { Random sequence generation (selection } \\
\text { bias) }\end{array}$ & Unclear risk & NR \\
\hline $\begin{array}{l}\text { Allocation concealment (selection bias) } \\
\begin{array}{l}\text { Blinding (performance bias and detection } \\
\text { bias) } \\
\text { All outcomes }\end{array}\end{array}$ & Unclear risk risk & NR \\
\hline Other bias & High risk & $\begin{array}{l}\text { Unavoidable in view of obvious difference } \\
\text { in treatment plan }\end{array}$ \\
\hline
\end{tabular}

\section{IFM94}

\begin{tabular}{ll} 
Methods & $\begin{array}{l}\text { Central randomisation at diagnosis } \\
\text { Multicentre }(\mathrm{N}=45) \text { RCT assessing superiority of TASCT } \\
2 \times 2 \text { factorial design: additional randomisation between bone marrow and peripheral } \\
\text { blood stem cells }\end{array}$ \\
\hline Participants & $\begin{array}{l}\text { TASCT N=200, SASCT N=199; (long-term follow-up: TASCT N=203; SASCT N= } \\
199) \\
\text { age }<60 \text { years } \\
\text { Previously untreated patients with MM Salmon-Durie stage I (with bone lesion), II-III } \\
\text { (Baseline characteristics Table 2) }\end{array}$ \\
\hline Interventions & $\begin{array}{l}\text { "Dose-escalating “TASCT regimen compared to SASCT (conditioning melphalan + TBI } \\
8 \text { Gy) - both either with bone marrow or peripheral blood stem cells } \\
\text { (Treatment regimen Table 3) }\end{array}$ \\
\hline Outcomes & $\begin{array}{l}\text { OS, EFS, treatment- and transplantation-related mortality in ITT population } \\
\text { (Definition of endpoints Table 4; Table 5) }\end{array}$ \\
\hline Notes & $\begin{array}{l}\text { Journal publication (peer review) } \\
\text { Long-term follow-up data for OS and EFS available } \\
\text { No clinically relevant interaction of two randomisations } \\
\text { Dose-escalating" TASCT regimen not comparable to current treatment approaches } \\
\text { (dose of first ASCT lower than only ASCT in SASCT arm) } \\
\text { Low compliance (75\%) with second ASCT in TASCT arm } \\
\text { Potential confounding subsequent salvage treatment (inferior post-relapse survival in } \\
\text { TASCT group) }\end{array}$ \\
\hline
\end{tabular}

\section{Risk of bias}

First-line tandem high-dose chemotherapy and autologous stem cell transplantation versus single high-dose chemotherapy and 


\begin{tabular}{|c|c|c|}
\hline Bias & Authors' judgement & Support for judgement \\
\hline $\begin{array}{l}\text { Random sequence generation (selection } \\
\text { bias) }\end{array}$ & Low risk & Central \\
\hline Allocation concealment (selection bias) & Low risk & Central \\
\hline $\begin{array}{l}\text { Blinding (performance bias and detection } \\
\text { bias) } \\
\text { All outcomes }\end{array}$ & High risk & $\begin{array}{l}\text { Unavoidable in view of obvious difference } \\
\text { in treatment plan }\end{array}$ \\
\hline Other bias & High risk & See Table 6 and Figure 2 \\
\hline
\end{tabular}

\section{MAG95}

\begin{tabular}{|c|c|}
\hline Methods & $\begin{array}{l}\text { Randomisation before induction treatment } \\
\text { Multicentre (number not reported) RCT without reporting of basic statistic assumption } \\
\text { (superiority/non-inferiority) } \\
\text { 2x2 factorial randomisation (unselected vs CD34 selected PBSC) }\end{array}$ \\
\hline Participants & $\begin{array}{l}\text { TASCT } \mathrm{N}=114 \text {, SASCT } \mathrm{N}=113 \\
\text { age }<56 \text { years } \\
\text { Previously untreated patients with MM Salmon-Durie stage II and III }\end{array}$ \\
\hline Interventions & $\begin{array}{l}\text { "Dose-escalating" TASCT vs SASCT (combination chemotherapy + } 12 \text { Gy TBI); both } \\
\text { with- and without selection of CD34-positive cells }\end{array}$ \\
\hline Outcomes & OS, median EFS; early death (toxic deaths for interim analysis, only) \\
\hline Notes & $\begin{array}{l}\text { Conference presentations } \\
\text { Clinically relevant interaction of two randomisations (inferior outcome after selection } \\
\text { of CD34+) } \\
\text { Non-standard conditioning regimen with high dose TBI (12 Gy) with asymmetric course } \\
\text { of toxicity between two arms (later onset of high toxicity in TASCT arm) } \\
\text { Potential confounding by subsequent salvage treatment (OS) }\end{array}$ \\
\hline
\end{tabular}

\section{Risk of bias}

\begin{tabular}{l|ll}
\hline Bias & Authors' judgement & Support for judgement \\
\hline $\begin{array}{l}\text { Random sequence generation (selection } \\
\text { bias) }\end{array}$ & Unclear risk & NR \\
\hline Allocation concealment (selection bias) & Unclear risk & NR \\
\hline $\begin{array}{l}\text { Blinding (performance bias and detection } \\
\text { bias) }\end{array}$ & High risk & $\begin{array}{l}\text { Unavoidable in view of obvious difference } \\
\text { ill outcomes treatment plan }\end{array}$ \\
\hline
\end{tabular}

First-line tandem high-dose chemotherapy and autologous stem cell transplantation versus single high-dose chemotherapy and 


\begin{tabular}{|c|c|c|}
\hline Other bias & High risk & See Table 6 and Figure 2 \\
\hline
\end{tabular}

\section{N0265041749}

\begin{tabular}{|c|c|c|}
\hline Methods & \multicolumn{2}{|c|}{$\begin{array}{l}\text { Randomised trial (no further information) following stem cell collection } \\
\text { Single centre RCT assessing superiority of TASCT }\end{array}$} \\
\hline Participants & \multicolumn{2}{|c|}{$\begin{array}{l}\text { No information on planned or recruited number of patients } \\
\text { age }<65 \text { years } \\
\text { Newly diagnosed (up to } 3 \text { months after diagnosis) patients with chemosensitive MM } \\
\text { Salmon-Durie stage II-III }\end{array}$} \\
\hline Interventions & \multicolumn{2}{|c|}{$\begin{array}{l}\text { Double vs single high-dose melphalan } \\
\text { (Treatment regimen Table 3) }\end{array}$} \\
\hline Outcomes & \multicolumn{2}{|l|}{ OS, quality of life } \\
\hline Notes & \multicolumn{2}{|c|}{$\begin{array}{l}\text { Register information (no clinical outcomes reported) } \\
\text { According to principal investigator study failed to recruit a "sufficient number of patients" }\end{array}$} \\
\hline \multicolumn{3}{|l|}{ Risk of bias } \\
\hline Bias & Authors' judgement & Support for judgement \\
\hline $\begin{array}{l}\text { Random sequence generation (selection } \\
\text { bias) }\end{array}$ & Unclear risk & NR \\
\hline Allocation concealment (selection bias) & Unclear risk & NR \\
\hline $\begin{array}{l}\text { Blinding (performance bias and detection } \\
\text { bias) } \\
\text { All outcomes }\end{array}$ & Unclear risk & NR \\
\hline Other bias & Unclear risk & NR \\
\hline
\end{tabular}

\section{Characteristics of excluded studies [ordered by study ID]}

\begin{tabular}{ll}
\hline Study & Reason for exclusion \\
\hline EBMTR & $\begin{array}{l}\text { Insufficient information on baseline characteristics (less than } 5 \text { factors without substantial missing data) } \\
\text { Insufficient information on treatment plan, already apparent imbalances between use of TBI in the "planned" or } \\
\text { "unplanned" group }\end{array}$
\end{tabular}




\begin{tabular}{|c|c|}
\hline Kim 2009 & No separate information on patients receiving either one or two transplants \\
\hline Koren 2010 & No separate information on patients receiving either one or two transplants \\
\hline Lahuerta 2003 & No separate information on patients receiving either one or two transplants \\
\hline NMSG & $\begin{array}{l}\text { Insufficient information on baseline characteristics (less than } 5 \text { factors) } \\
\text { Insufficient information on treatment plan. }\end{array}$ \\
\hline Sonneveld 2007 & Non-myeloablative dosing regimen of melphalan $\left(2 \times 70 \mathrm{mg} / \mathrm{m}^{2}\right)$ \\
\hline Total therapy & $\begin{array}{l}\text { No RCT. } \\
\text { No contemporary control group. } \\
\text { Of note: integration of novel agents in TT generation }>1 \text { is regarded as a critically different treatment approach } \\
\text { compared to the set of included RCTs }\end{array}$ \\
\hline
\end{tabular}

\section{Characteristics of ongoing studies [ordered by study ID]}

\section{NCT01109004}

Trial name or title A trial of single autologous transplantation with or without consolidation therapy versus tandem autologous transplantation with lenalidomide maintenance for patients with MM (BMT CTN 0702)

\begin{tabular}{|c|c|}
\hline Methods & Randomised, multicenter $(\mathrm{N}=52)$, open-label, three-arm trial \\
\hline Participants & $\begin{array}{l}\text { Up to } 750 \text { patients with symptomatic MM who have received at least two cycles of any regimen as initial } \\
\text { systemic therapy and are within } 2-12 \text { months of the first dose of initial therapy and with an adequate } \\
\text { autologous graft } \\
<70 \text { years }\end{array}$ \\
\hline Interventions & $\begin{array}{l}\text { TASCT plus maintenance therapy versus the strategy of SASCT plus consolidation therapy with lenalidomide, } \\
\text { bortezomib and dexamethasone (RVD) followed by maintenance therapy or SASCT plus maintenance therapy } \\
\text { as part of upfront treatment of MM. Lenalidomide will be used as maintenance therapy for three years in all } \\
\text { arms }\end{array}$ \\
\hline Outcomes & Primary 3 year PFS, 3 year OS, Quality of life, treatment-related mortality \\
\hline Starting date & May 2010 - May 2016 (estimated final data collection date for primary outcome measure) \\
\hline Contact information & $\begin{array}{l}\text { Mary Horowitz, MD, MS http://clinicaltrials.gov/ct2/show/NCT01109004?term=NCT01109004\&lup_s= } \\
\text { 01\%2F30\%2F2011\&lup_d=30 }\end{array}$ \\
\hline Notes & \\
\hline
\end{tabular}


DATA AND ANALYSES

This review has no analyses.

ADDITIONAL TABLES

Table 1. Searching for trials: Inclusion and exclusion criteria for eligibility

\section{General aspects}

\begin{tabular}{ll}
\hline Accepted study designs & Studies with contemporary control groups (RCT or observational) \\
\hline Accepted date of publication & $1995-2011$ \\
\hline Accepted publication type & $\begin{array}{l}\text { RCTs: full text, abstract, conference presentation } \\
\text { Observational studies: full-text only }\end{array}$ \\
\hline Inclusion criteria & $\begin{array}{l}\text { Patients with previously untreated symptomatic MM (excluding the prognostically very different } \\
\text { plasma cell leukaemia (International Myeloma Workshop 2003)) comprising at least 85\% of the study } \\
\text { population }\end{array}$ \\
\hline I1 & \begin{tabular}{l} 
Intervention group: tandem autologous stem cell transplantation \\
\hline I2
\end{tabular} \\
\hline I3 & $\begin{array}{l}\text { Control group: single autologous stem cell transplantation } \\
\text { mortality) }\end{array}$ \\
\hline I4 &
\end{tabular}

I5

Observational studies: comparability of study groups with detailed information for at least 5 relevant prognostic criteria per arm

\section{Exclusion criteria}

Other research questions (e.g. basic research, other therapeutic approaches, other diseases, prognostic studies) or publication type (e.g. narrative review, editorial, letter without original data)

Duplicate publication without additional information ${ }^{1}$

E3

Report without quantifiable/assignable outcome measures of first-line treatment in patients with MM

E4

No acceptable study design (or, in addition, publication type for observational studies)

E5

Low number of evaluable patients per arm $(<25$ patients per arm for RCTs, $<50$ for observational studies) $)^{2}$

Other Language of publication than English, French or German

1 For cumulative reports such as registry data, only the last publication was included. Abstract presentations of included RCTs published in full-text were only included if they contained additional data (e.g. long-term follow-up).

First-line tandem high-dose chemotherapy and autologous stem cell transplantation versus single high-dose chemotherapy and 33 autologous stem cell transplantation in multiple myeloma, a systematic review of controlled studies (Review)

Copyright (C) 2012 The Cochrane Collaboration. Published by John Wiley \& Sons, Ltd. 
2 In view of the lower relevance of non-randomised studies for assessment of intervention effects, larger studies were required for inclusion.

Table 2. Baseline characteristics of patients

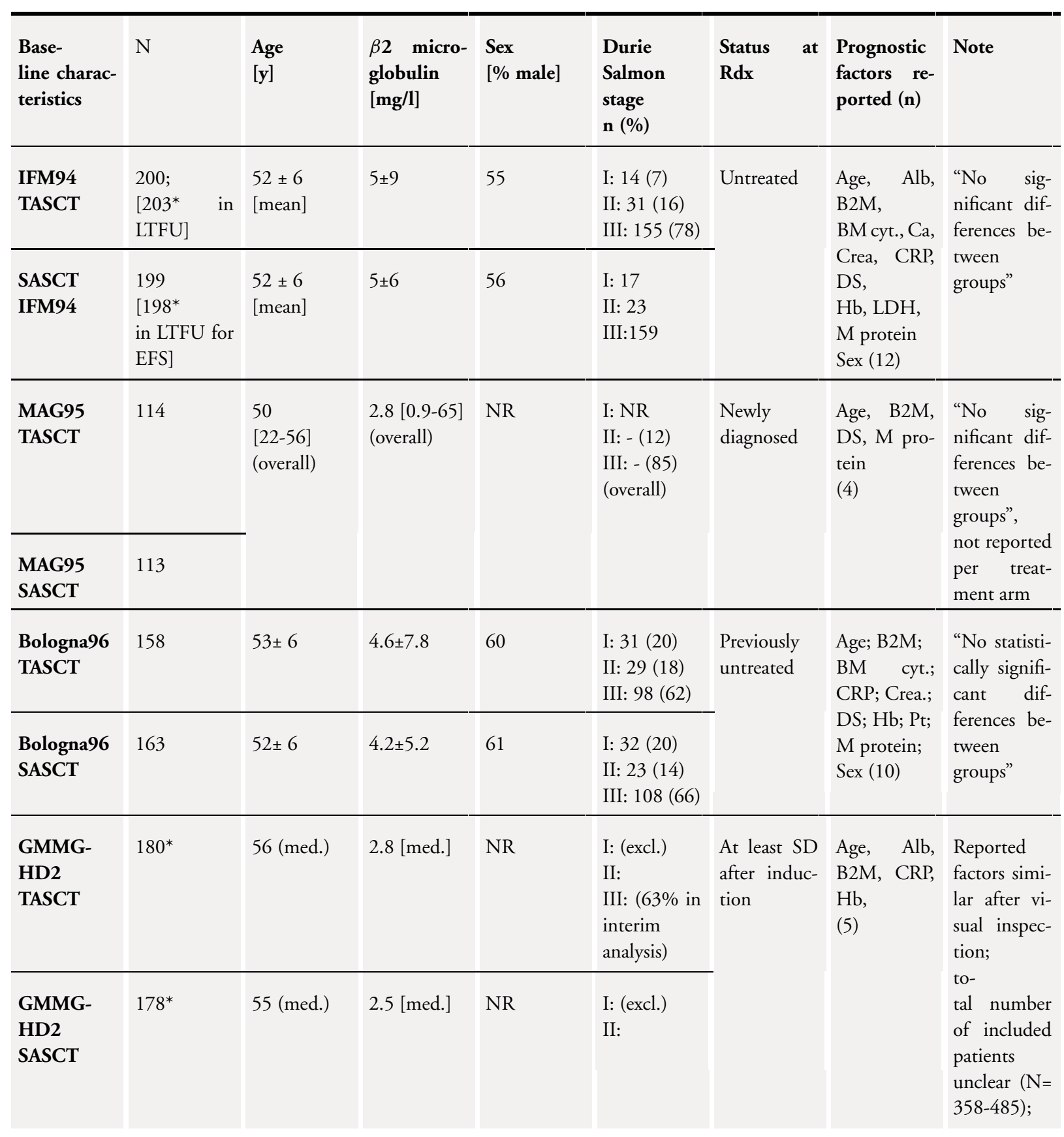

First-line tandem high-dose chemotherapy and autologous stem cell transplantation versus single high-dose chemotherapy and 34 autologous stem cell transplantation in multiple myeloma, a systematic review of controlled studies (Review) Copyright (C) 2012 The Cochrane Collaboration. Published by John Wiley \& Sons, Ltd. 
Table 2. Baseline characteristics of patients (Continued)

\begin{tabular}{|c|c|c|c|c|c|c|c|c|}
\hline & & & & & $\begin{array}{l}\text { III: (70\% in } \\
\text { interim } \\
\text { analysis) }\end{array}$ & & & \\
\hline $\begin{array}{l}\text { DSMM-I } \\
\text { TASCT } \\
\text { (immature) }\end{array}$ & 98 & $\begin{array}{l}54 \\
(30-60)\end{array}$ & $\begin{array}{l}{[>3.5 \mathrm{~g} / \mathrm{dl}]} \\
31.6 \%\end{array}$ & 63 & $\begin{array}{l}\text { I: (excl.) } \\
\text { II: } 28 \% \\
\text { III: } 72 \%\end{array}$ & \multirow{2}{*}{$\begin{array}{l}\text { At least SD } \\
\text { after induc- } \\
\text { tion and suf- } \\
\text { ficient num- } \\
\text { ber } \\
\text { of stem cells } \\
\text { collected }\end{array}$} & \multirow{2}{*}{$\begin{array}{l}\text { Age, } \\
\text { B2M, Crea, } \\
\text { DS, LDH, } \\
\text { M protein, } \\
\text { bone, } \\
\text { sex } \\
(8)\end{array}$} & \multirow{2}{*}{$\begin{array}{l}\text { "No statisti- } \\
\text { cally signifi- } \\
\text { cant dif- } \\
\text { ferences be- } \\
\text { tween } \\
\text { groups" }\end{array}$} \\
\hline $\begin{array}{l}\text { DSMM-I } \\
\text { SASCT } \\
\text { (immature) }\end{array}$ & 100 & $\begin{array}{l}54 \\
(34-61)\end{array}$ & $\begin{array}{l}{[>3.5 \mathrm{~g} / \mathrm{dl}]} \\
29 \%\end{array}$ & 63 & $\begin{array}{l}\text { I: (excl.) } \\
\text { II: } 38 \% \\
\text { III: } 62 \%\end{array}$ & & & \\
\hline
\end{tabular}

rounded figures; Alb: serum albumin; B2M: $\beta 2$ microglobulin; BM cyt: bone marrow cytosis; Ca: serum calcium; Crea: serum creatinine; CRP: C-reactive protein; DS: Durie-Salmon stage; Hb: haemoglobin; LDH: serum lactate dehydrogenase, LTFU: long-term followup; Pt: platelets; Rdx: randomisation

- median OS read of KM curves; * evaluated patients

Table 3. Treatment regimen in included studies

\begin{tabular}{|c|c|c|c|c|c|c|c|c|}
\hline Study & $\begin{array}{l}\text { Stem cell } \\
\text { mobilisa- } \\
\text { tion/ } \\
\text { source } \\
\text { (type; mini- } \\
\text { mal } \\
\text { number per } \\
\text { transplant }\end{array}$ & Induction & $\begin{array}{l}\text { Condition- } \\
\text { ing ASCT }\end{array}$ & $\begin{array}{l}\text { Compli- } \\
\text { ance ASCT }\end{array}$ & $\begin{array}{l}\text { Mainte- } \\
\text { nance } \\
\text { [Compli- } \\
\text { ance] }\end{array}$ & Salvage & $\begin{array}{l}\text { Cross-over } \\
\text { (SASCT to } \\
\text { TASCT) }\end{array}$ & Notes \\
\hline $\begin{array}{l}\text { IFM94 } \\
\text { TASCT }\end{array}$ & $\begin{array}{l}\text { G-CSF } \\
\text { for PBSC or } \\
\text { BM harvest } \\
\text { after induc- } \\
\text { tion; } \\
\text { (PBSC or } \\
\text { BM; 2*106 } \\
\text { CD34+ } / \mathrm{kg})\end{array}$ & 3-4 x VAD & $\begin{array}{l}\text { 1. Mel } 140 \\
\text { 2. Mel } 140+ \\
8 \text { Gy TBI }\end{array}$ & $\begin{array}{ll}\text { 1. } & 88 \% \\
\text { 2. } & 78 \%\end{array}$ & $\begin{array}{l}\text { Interferon } \\
\alpha ; \\
{[49 \%]}\end{array}$ & $\begin{array}{l}59 \% \text {, } \\
\text { e.g. } \\
21 \% \text { Thal., } \\
17 \% \text { SCT }\end{array}$ & I & \multirow[t]{2}{*}{$\begin{array}{l}\text { 2nd rdx } \\
\text { BM/PBSC } \\
\text { no clinically } \\
\text { relevant in- } \\
\text { teraction; } \\
\text { differ- } \\
\text { ent dose in- } \\
\text { tensity up to } \\
\text { first ASCT; }\end{array}$} \\
\hline $\begin{array}{l}\text { IFM94 } \\
\text { SASCT }\end{array}$ & as TASCT & as TASCT & $\begin{array}{l}\text { Mel } 140+ \\
8 \text { Gy TBI }\end{array}$ & $85 \%$ & $\begin{array}{l}\text { Interferon } \\
\alpha ; \text { steroids; } \\
{[57 \%]}\end{array}$ & $\begin{array}{l}68 \% \text { e.g. } \\
12 \% \text { Thal., } \\
17 \% \text { SCT }\end{array}$ & NR & \\
\hline $\begin{array}{l}\text { MAG95 } \\
\text { TASCT }\end{array}$ & $\begin{array}{l}\text { CYP, G- } \\
\text { CSF; } \\
\text { PBSC } \\
\text { (PBSC; NR) }\end{array}$ & $\begin{array}{l}\text { HD steroids } \\
\text { and? }\end{array}$ & $\begin{array}{l}\text { 1. Mel } 140 \\
\text { 2. Mel } 140 \\
+ \text { VP16 } \\
+12 \text { Gy TBI }\end{array}$ & $\begin{array}{l}\text { 1st: } 100 \% \\
2 \text { nd: } 92 \%\end{array}$ & NR or none & NR & I & $\begin{array}{l}\text { Stem cell } \\
\text { col- } \\
\text { lection after } \\
\text { high-dose } \\
\text { steroids; }\end{array}$ \\
\hline
\end{tabular}

First-line tandem high-dose chemotherapy and autologous stem cell transplantation versus single high-dose chemotherapy and 
Table 3. Treatment regimen in included studies (Continued)

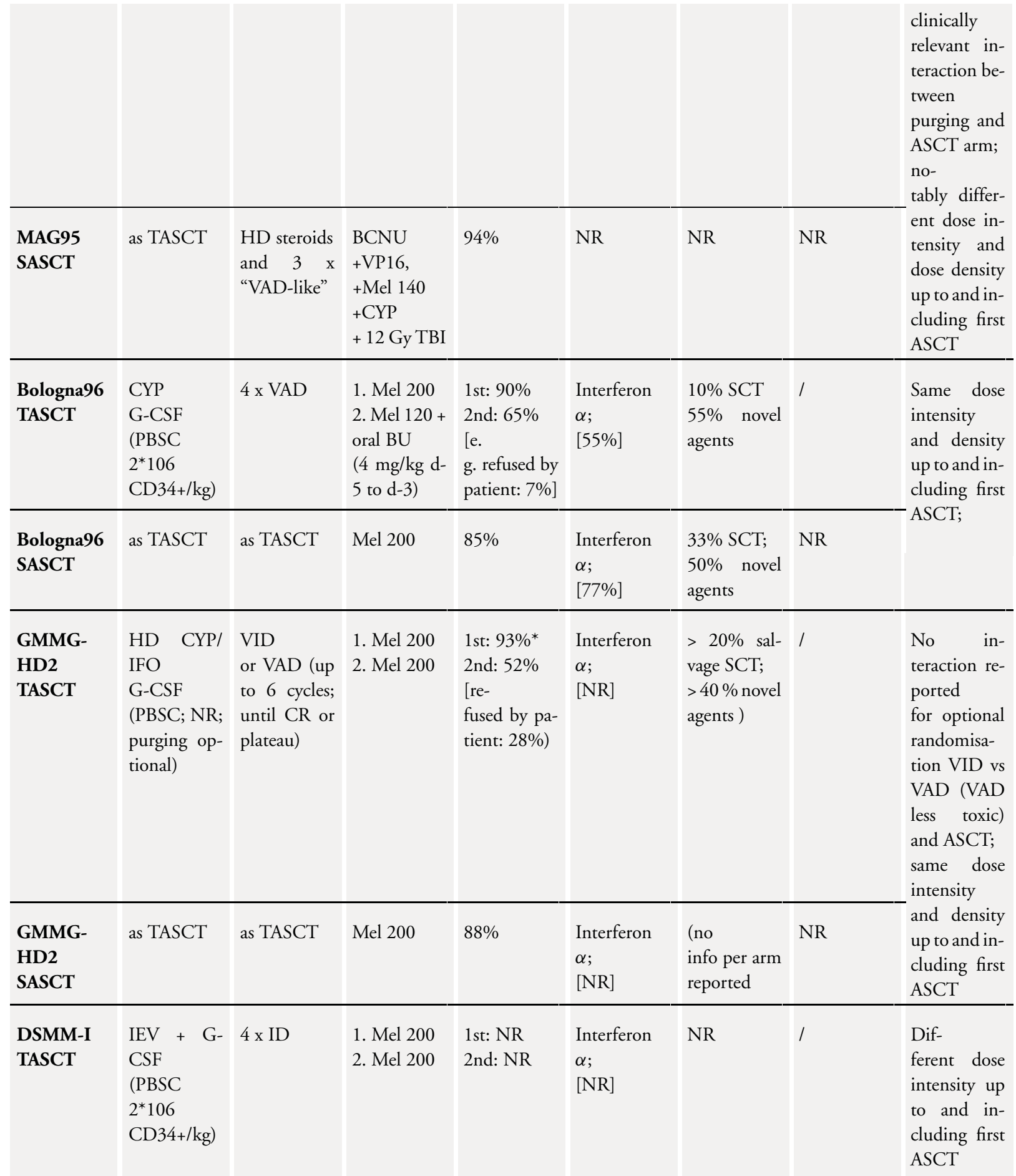

First-line tandem high-dose chemotherapy and autologous stem cell transplantation versus single high-dose chemotherapy and 
Table 3. Treatment regimen in included studies (Continued)

\begin{tabular}{|c|c|c|c|c|c|c|c|}
\hline $\begin{array}{l}\text { DSMM-I } \\
\text { SASCT }\end{array}$ & as TASCT & as TASCT & $\begin{array}{l}\text { BU CYP } \\
+9 \text { Gy TMI }\end{array}$ & $72 \%$ & $\begin{array}{l}\text { Interferon } \\
\alpha ; \\
{[\mathrm{NR}]}\end{array}$ & NR & $\begin{array}{l}18 \% \text { (time } \\
\text { point not re- } \\
\text { ported) }\end{array}$ \\
\hline $\begin{array}{l}\text { Current } \\
\text { standard } \\
\text { and report- } \\
\text { ing recom- } \\
\text { mendations }\end{array}$ & $\begin{array}{l}\text { HD CYP + } \\
\text { G-CSF; } \\
\text { unselected } \\
\text { graft }\end{array}$ & $\begin{array}{l}\text { novel agent } \\
\text { plus dexam- } \\
\text { ethasone }\end{array}$ & $\begin{array}{l}\text { Mel 200; } \\
\text { no TBI }\end{array}$ & $\begin{array}{l}\text { Consider to } \\
\text { in- } \\
\text { crease num- } \\
\text { ber of drop- } \\
\text { out for sam- } \\
\text { ple size cal- } \\
\text { culation }\end{array}$ & $\begin{array}{l}\text { Report com- } \\
\text { pliance per } \\
\text { arm }\end{array}$ & $\begin{array}{l}\text { Report } \\
\text { number of } \\
\text { patients and } \\
\text { outcome per } \\
\text { arm }\end{array}$ & $\begin{array}{l}\text { Report } \\
\text { number of } \\
\text { patients and } \\
\text { time point/ } \\
\text { status } \\
\text { at cross-over } \\
\text { per arm; }\end{array}$ \\
\hline
\end{tabular}

BM: bone marrow; BCNU: carmustine; BU: busulfan; CD34: cluster of differentiation (stem cell marker); CR: complete response; CYP: cyclophosphamide; G-CSF: granulocyte-colony stimulating factor; Gy: Gray; HD: high-dose; IFO: ifosfamide; IEV: Ifosfamide, epirubicin, etoposide; ID: idarubicin, dexamethasone; Mel: Melphalan; NR: not reported; PBSC: peripheral blood stem cells; rdx: randomisation; SCT: stem cell transplant; TBI: total body irradiation; TMI: total marrow irradiation; VAD: vincristine, adriamycin,

dexamethasone; VID: vincristine, idarubicine, dexamethasone

VP16 etoposide

* of evaluated patients

Table 4. Definition of survival outcomes

\begin{tabular}{|c|c|c|c|c|c|c|c|c|}
\hline Study & do & OS & EFS & $\begin{array}{l}\text { Response } \\
\text { criteria }\end{array}$ & Progression & Relapse & $\begin{array}{l}\text { Follow up } \\
\text { (med.) }\end{array}$ & Note \\
\hline IFM94 & Diagnosis & Death & $\begin{array}{l}\text { Progression } \\
\text { relapse } \\
\text { death }\end{array}$ & $\begin{array}{l}\text { IFM (pre- } \\
\text { EBMT) } \\
\text { methods } \\
\text { without im- } \\
\text { munofixa- } \\
\text { tion, i.e. over- } \\
\text { estimation of } \\
\text { CR }\end{array}$ & $\begin{array}{l}25 \% \text { increase } \\
\text { in the para- } \\
\text { protein level } \\
\text { after two cy- } \\
\text { cles of the ini- } \\
\text { tial chemo- } \\
\text { therapy; }\end{array}$ & $\begin{array}{l}\text { After CR } \\
\text { reappearance } \\
\text { of M-protein, } \\
\text { recurrence of } \\
\text { bone marrow } \\
\text { infiltration, } \\
\text { or both } \\
\text { after response } \\
50 \% \text { increase } \\
\text { above } \\
\text { the plateau of } \\
\text { M-protein in } \\
\text { two sam- } \\
\text { ples obtained } \\
4 \text { weeks apart }\end{array}$ & $\begin{array}{l}75 \mathrm{mo} / \\
11.6 \mathrm{y}\end{array}$ & $\begin{array}{l}\text { Including pe- } \\
\text { riod of induc- } \\
\text { tion and mo- } \\
\text { bilisation, } \\
\text { lower sensi- } \\
\text { tivity with re- } \\
\text { spect to } \\
\text { detecting re- } \\
\text { lapse without } \\
\text { immunofixa- } \\
\text { tion }\end{array}$ \\
\hline MAG95 & $\begin{array}{l}\text { After HD } \\
\text { steroids be- } \\
\text { fore mobili- } \\
\text { sation }\end{array}$ & NR & NR & NR & NR & NR & $73 \mathrm{mo}$ & $\begin{array}{l}\text { Including pe- } \\
\text { riod of induc- } \\
\text { tion and mo- } \\
\text { bilisation }\end{array}$ \\
\hline
\end{tabular}

First-line tandem high-dose chemotherapy and autologous stem cell transplantation versus single high-dose chemotherapy and 37 autologous stem cell transplantation in multiple myeloma, a systematic review of controlled studies (Review) Copyright (C) 2012 The Cochrane Collaboration. Published by John Wiley \& Sons, Ltd. 
Table 4. Definition of survival outcomes (Continued)

\begin{tabular}{|c|c|c|c|c|c|c|c|c|}
\hline Bologna96 & $\begin{array}{l}\text { Start of } \\
\text { treatment }\end{array}$ & Death & $\begin{array}{l}\text { Progression } \\
\text { relapse } \\
\text { death }\end{array}$ & $\begin{array}{l}\text { EBMT+ } \\
\text { nCR } \\
\text { (=CR } \\
\text { with positive } \\
\text { immunofixa- } \\
\text { tion) }\end{array}$ & $\begin{array}{l}\text { Respon- } \\
\text { ders: > 25\% } \\
\text { increase in M } \\
\text { protein from } \\
\text { nadir and/or } \\
\text { appearance of } \\
\text { new bone } \\
\text { lytic lesions } \\
\text { non-respon- } \\
\text { ders: > 25\% } \\
\text { increase in M } \\
\text { protein from } \\
\text { baseline and/ } \\
\text { or appear- } \\
\text { ance of new } \\
\text { bone lytic le- } \\
\text { sions }\end{array}$ & $\begin{array}{l}\text { After CR/ } \\
\text { nCR } \\
\text { reappearance } \\
\text { of } \mathrm{M} \text { pro- } \\
\text { tein on im- } \\
\text { munofix- } \\
\text { ation or rou- } \\
\text { tine electro- } \\
\text { phoresis, re- } \\
\text { spec- } \\
\text { tively, and/or } \\
\text { appearance of } \\
\text { new bone } \\
\text { lytic lesions }\end{array}$ & $\begin{array}{l}70 \text { mo (sur- } \\
\text { vivors only) }\end{array}$ & $\begin{array}{l}\text { Including pe- } \\
\text { riod of induc- } \\
\text { tion and mo- } \\
\text { bilisation }\end{array}$ \\
\hline $\begin{array}{l}\text { GMMG- } \\
\text { HD2 }\end{array}$ & Unclear & NR & NR & NR & NR & NR & $\begin{array}{l}\text { Unclear } \\
\text { 2003: } \\
\text { months } \\
\text { 2005: } 24 \\
\text { months } \\
\text { 2007: NR }\end{array}$ & $\begin{array}{l}\text { Refer- } \\
\text { ence point for } \\
\text { time-to event } \\
\text { and follow- } \\
\text { up unclear; } \\
\text { likely exclud- } \\
\text { ing induction } \\
\text { but including } \\
\text { mobilisation } \\
\text { in selected } \\
\text { patients }\end{array}$ \\
\hline DSMM-I & Unclear & NR & NR & NR & NR & NR & 48 mo total?? & $\begin{array}{l}\text { Refer- } \\
\text { ence point for } \\
\text { time-to event } \\
\text { and follow- } \\
\text { up unclear; so } \\
\text { called TRM } \\
\text { of } \\
4 \% \text { reported } \\
\text { for TASCT } \\
\text { arm but OS } \\
\text { at } 100 \% \text { for } \\
500 \text { days of } \\
\text { FU }\end{array}$ \\
\hline
\end{tabular}

CR: complete response; EBMT: European Bone Marrow Transplantation; FU: follow-up; IFM: Intergroupe francophone du myelome; med: median; mo: months; nCR: near complete response 
Table 5. Defition of treatment- or transplant-related mortality

\begin{tabular}{|c|c|c|c|c|c|}
\hline Study & Definition used & $\begin{array}{l}\text { How reported } \\
\text { in which popula- } \\
\text { tion }\end{array}$ & $\begin{array}{l}\text { Start } \\
\text { point }\end{array}$ & Period & $\begin{array}{l}\text { Other causes of death reported sepa- } \\
\text { rately }\end{array}$ \\
\hline IFM94 & $\begin{array}{l}\text { Treatment-related } \\
\text { mortality: } \\
\text { "toxic effects of } \\
\text { transplantation (sep- } \\
\text { sis)" } \\
\text { "toxic effects to VAD } \\
\text { (sepsis)" }\end{array}$ & $\begin{array}{l}\text { number of deaths; } \% \\
\text { per arm; ITT }\end{array}$ & Unclear & NR & $\begin{array}{l}\text { "Death due to myeloma"; } \\
\text { "cardiovascular or thrombo- } \\
\text { embolic disease" } \\
\text { "another cancer" } \\
\text { "unknown cause" } \\
\text { "suicide" }\end{array}$ \\
\hline MAG95[1] & $\begin{array}{l}\text { Interim analysis: } \\
\text { "Toxic death" } \\
\text { (performed with } \\
85 \% \text { of final popula- } \\
\text { tion) } \\
\text { Final analysis "Early } \\
\text { death" } \\
\text { "death within } \\
9 \text { months post ran- } \\
\text { domisation includ- } \\
\text { ing toxic death and } \\
\text { fatal progressive dis- } \\
\text { ease" } 2\end{array}$ & $\begin{array}{l}\% \text { per arm; popula- } \\
\text { tion NR } \\
\text { (for both definitions) }\end{array}$ & $\mathrm{Rdx}$ & 9 months & NR \\
\hline Bologna96 & $\begin{array}{l}\text { "Transplan- } \\
\text { tation-related mor- } \\
\text { tality included any } \\
\text { death within } 90 \text { days } \\
\text { and attributable to } \\
\text { high-dose therapy" }\end{array}$ & $\begin{array}{l}\% \text { per arm; } \\
\text { population NR }\end{array}$ & SCT & 90 days & $\begin{array}{l}\text { N of deaths as reason for non-compliance } \\
\text { (no cause of death reported) }\end{array}$ \\
\hline GMMG-HD2 & $\begin{array}{l}\text { So-called } \\
\text { TRM (treatment or } \\
\text { transplantation?) } \\
\text { reported without the } \\
\text { clarification of popu- } \\
\text { lation }\end{array}$ & $\begin{array}{l}\% \text { per transplanta- } \\
\text { tion per arm; popula- } \\
\text { tion } \mathrm{NR}^{3}\end{array}$ & NR & NR & NR \\
\hline DSMM-I & $\begin{array}{l}\text { So-called } \\
\text { TRM (treatment or } \\
\text { transplantation?) }\end{array}$ & $\begin{array}{l}\% \text { per arm; popula- } \\
\text { tion NR }\end{array}$ & NR & $\mathrm{NR}^{*}$ & NR \\
\hline
\end{tabular}

1 toxic death lower in TASCT compared to SASCT arm (7\% versus 9\%)

2 notable difference in dose intensity between TASCT and SASCT resulting in $7 \%$ versus $12 \%$ early mortality.

First-line tandem high-dose chemotherapy and autologous stem cell transplantation versus single high-dose chemotherapy and 
3 only $56 \%$ compliance with second ASCT

* plateau of $100 \%$ in Kaplan-Meier curve from d1-d400 in TASCT arm despite so-called TRM of 4\%; reported safety population for SASCT N=80; TASCT N=118 since 20 patients crossed over from SASCT to TASCT arm

Table 6. Quality criteria for the assessment of bias

\begin{tabular}{|c|c|c|c|c|}
\hline Quality criteria & positive & negative & unclear & $\begin{array}{l}\text { Consequence of nega- } \\
\text { tive classification }\end{array}$ \\
\hline \multicolumn{5}{|l|}{ RCT } \\
\hline Central randomisation & $\begin{array}{l}\text { Performed with ade- } \\
\text { quate methods described }\end{array}$ & $\begin{array}{l}\text { Inadequate methods de- } \\
\text { scribed }\end{array}$ & Not Reported (NR) & Confounding \\
\hline $\begin{array}{l}\text { Concealment of alloca- } \\
\text { tion }\end{array}$ & $\begin{array}{l}\text { Performed with ade- } \\
\text { quate methods described }\end{array}$ & $\begin{array}{l}\text { Inadequate methods de- } \\
\text { scribed }\end{array}$ & NR & Confounding \\
\hline Statistical power & Powered for survival & Powered for response & NR & $\begin{array}{l}\text { Underpowered for sur- } \\
\text { vival }\end{array}$ \\
\hline \multicolumn{5}{|l|}{ Observational studies } \\
\hline Selection of patients & $\begin{array}{l}\text { Based on transparent cri- } \\
\text { teria; plausible matching } \\
\text { criteria }\end{array}$ & $\begin{array}{l}\text { Indicative of strong se- } \\
\text { lection bias; resulting in } \\
\text { incomparable groups }\end{array}$ & NR & Confounding \\
\hline Study size & Justified & $\begin{array}{l}\text { Fewer patients than } \\
\text { planned }\end{array}$ & NR & Underpowered for OS \\
\hline
\end{tabular}

\section{RCT and observational study}

\begin{tabular}{|c|c|c|c|c|}
\hline Confounding at baseline & $\begin{array}{l}\text { Reporting of at least } 5 \\
\text { key prognostic factors } \\
\text { per arm allowing assess- } \\
\text { ment of similarity of } \\
\text { groups }\end{array}$ & $\begin{array}{l}\text { Relevant difference in } \\
\text { key prognostic factors } \\
\text { obviously present clini- } \\
\text { cally but not addressed }\end{array}$ & $\begin{array}{l}<l=5 \text { factors reported or } \\
\text { no information per arm }\end{array}$ & Confounding \\
\hline $\begin{array}{l}\text { Comparability of treat- } \\
\text { ment }\end{array}$ & $\begin{array}{l}\text { Treatment identical up } \\
\text { to and including first } \\
\text { ASCT }\end{array}$ & $\begin{array}{l}\text { Notable difference with } \\
\text { onset and duration of } \\
\text { toxic treatment }\end{array}$ & Unclear & $\begin{array}{l}\text { Lead-time bias/ } \\
\text { confounding }\end{array}$ \\
\hline Subsequent treatment & $\begin{array}{l}\text { Information avail- } \\
\text { able with type and out- } \\
\text { come per arm }\end{array}$ & $\begin{array}{l}\text { No information avail- } \\
\text { able }\end{array}$ & NR or no info per arm & Confounding \\
\hline ITT analysis & $\begin{array}{l}\text { Yes, including definition } \\
\text { reported }\end{array}$ & No & $\begin{array}{l}\text { Analysis or definition } \\
\text { NR }\end{array}$ & $\begin{array}{l}\text { Selection and attrition } \\
\text { bias with loss of power }\end{array}$ \\
\hline $\begin{array}{l}\text { Compliance with 2nd } \\
\text { TASCT }\end{array}$ & High $(>85 \%)$ & Low $(<70 \%)$ & $\begin{array}{l}70-85 \% \\
\text { or NR }\end{array}$ & $\begin{array}{l}\text { Attrition bias }{ }^{1} \text { or loss of } \\
\text { power }^{2}\end{array}$ \\
\hline
\end{tabular}




\begin{tabular}{|c|c|c|c|c|}
\hline $\begin{array}{l}\text { Completeness of follow- } \\
\text { up }\end{array}$ & $\begin{array}{l}<15 \% \text { loss to follow-up; } \\
\text { censoring rules defined }\end{array}$ & $\begin{array}{l}\text { Incomplete follow-up (> } \\
15 \% \text { with unknown } \\
\text { consequence for analysis }\end{array}$ & $\begin{array}{l}\text { Loss to follow-up or cen- } \\
\text { soring rules NR }\end{array}$ & $\begin{array}{l}\text { Attrition bias }{ }^{1} \text { or loss of } \\
\text { power }^{2}\end{array}$ \\
\hline Cross-over & Reported and $<15 \%$ & Reported and $>15 \%$ & NR & Null bias \\
\hline Definition of endpoints & $\begin{array}{l}\text { Comprehensive report- } \\
\text { ing of accepted/ estab- } \\
\text { lished endpoint defini- } \\
\text { tions }\end{array}$ & $\begin{array}{l}\text { Use of biased endpoint } \\
\text { (e.g. different period of } \\
\text { observation for study } \\
\text { arms) }\end{array}$ & Incomplete reporting* & Lack of scientific validity \\
\hline $\begin{array}{l}\text { Standardisation of diag- } \\
\text { nostic procedures or cen- } \\
\text { tral review }\end{array}$ & $\begin{array}{l}\text { Mentioning of standard- } \\
\text { isation efforts, use of ac- } \\
\text { cepted staging systems }\end{array}$ & $\begin{array}{l}\text { Reporting of centre ef- } \\
\text { fects or major changes } \\
\text { in diagnostic criteria over } \\
\text { the course of the study }\end{array}$ & NR & $\begin{array}{l}\text { Information bias (if sys- } \\
\text { tematically different be- } \\
\text { tween arms) }\end{array}$ \\
\hline $\begin{array}{l}\text { Data maturity (Tricot } \\
\text { 2009) }\end{array}$ & $>4$ years follow-up (FU) & Less than 4 years FU & NR & Insufficient follow-up \\
\hline $\begin{array}{l}\text { Publication } \\
\text { type\& }\end{array}$ & Peer-reviewed full-text & $\begin{array}{l}\text { Conference } \\
\text { presentations }\end{array}$ & Not Applicable (NA) & $\begin{array}{l}\text { Error-prone } \\
\text { due to less proof-reading } \\
\text { (at the least) }\end{array}$ \\
\hline \multicolumn{5}{|l|}{$\begin{array}{l}\text { NR not reported } \\
{ }^{1} \text { if informative censoring }\end{array}$} \\
\hline
\end{tabular}

Table 7. Effect of TASCT compared to SASCT on OS, EFS and "TRM"

\begin{tabular}{|c|c|c|c|c|c|c|c|c|c|c|}
\hline \multirow[b]{2}{*}{ Study } & \multirow[t]{2}{*}{$\begin{array}{l}\text { Follow- } \\
\text { up } \\
\text { months } \\
\text { (mo) }\end{array}$} & \multirow{2}{*}{$\begin{array}{l}\begin{array}{l}\text { Kaplan- } \\
\text { Meier } \\
\text { curve }\end{array} \\
\text { OS }\end{array}$} & \multicolumn{2}{|c|}{ Median OS } & \multirow{2}{*}{$\begin{array}{l}\begin{array}{l}\text { Kaplan- } \\
\text { Meier } \\
\text { curve }\end{array} \\
\text { EFS }\end{array}$} & \multicolumn{2}{|c|}{ Median EFS } & \multicolumn{2}{|c|}{$\begin{array}{l}\text { Treatment- or Trans- } \\
\text { plant-related mortal- } \\
\text { ity }\end{array}$} & \multirow[t]{2}{*}{ Notes } \\
\hline & & & TASCT & SASCT & & TASCT & SASCT & TASCT & SASCT & \\
\hline IFM94 & $\begin{array}{l}75 \text { mo } \\
\text { (median) }\end{array}$ & $\begin{array}{l}\text { TASCT } \\
\text { superior; } \\
\text { sep- } \\
\text { aration of } \\
\text { curves af- } \\
\text { ter ca. } 26 \\
\text { mo; }\end{array}$ & $58 \mathrm{mo}^{*}$ & $\begin{array}{l}48 \mathrm{mo}^{*} \\
\mathrm{P}=0.01\end{array}$ & $\begin{array}{l}\text { TASCT } \\
\text { superior; } \\
\text { sep- } \\
\text { aration of } \\
\text { curves af- } \\
\text { ter ca. } 18 \\
\text { mo; }\end{array}$ & $30 \mathrm{mo}^{*}$ & $\begin{array}{l}25 \mathrm{mo}^{*} \\
\mathrm{P}=0.03\end{array}$ & $\begin{array}{l}\text { Treat- } \\
\text { ment- } \\
\text { related } \\
\text { deaths } \\
\text { (includ- } \\
\text { ing in- } \\
\text { duction) } \\
\mathrm{N}=\quad 12 \\
(6 \%)\end{array}$ & $\begin{array}{l}\text { Treat- } \\
\text { ment- } \\
\text { related } \\
\text { deaths } \\
\text { (includ- } \\
\text { ing in- } \\
\text { duction) } \\
\mathrm{N}=\quad 8 \\
(4 \%)\end{array}$ & $\begin{array}{l}\text { Five addi- } \\
\text { tional } \\
\text { causes of } \\
\text { death } \\
\text { listed; } \\
\text { Long } \\
\text { term fol- } \\
\text { low- } \\
\text { up (11.6 }\end{array}$ \\
\hline
\end{tabular}


Table 7. Effect of TASCT compared to SASCT on OS, EFS and “TRM" (Continued)

\begin{tabular}{|c|c|c|c|c|c|c|c|c|c|c|}
\hline & & & & & & & & $\begin{array}{l}\text { Trans- } \\
\text { planta- } \\
\text { tion- } \\
\text { related } \\
\text { deaths } \\
\text { (sepsis) } \\
\mathrm{N}=5\end{array}$ & $\begin{array}{l}\text { Trans- } \\
\text { planta- } \\
\text { tion- } \\
\text { related } \\
\text { deaths } \\
\text { (sepsis) } \\
\mathrm{N}=3\end{array}$ & $\begin{array}{l}\text { years) } \\
\text { OS P=0. } \\
08 \\
\text { EFS } P=0 \\
06\end{array}$ \\
\hline MAG95 & $\begin{array}{l}73 \text { mo } \\
\text { (median) }\end{array}$ & $\begin{array}{l}\text { SASCT } \\
\text { inferior; } \\
\text { (overall } \\
\text { transient) } \\
\text { sep- } \\
\text { aration of } \\
\text { curves af- } \\
\text { ter cluster } \\
\text { of events } \\
\text { in control } \\
\text { arm after } \\
2- \\
4 \text { and } 35 \\
\text { months; }\end{array}$ & $75 \mathrm{mo}$ & $57 \mathrm{mo}$ & $\begin{array}{l}\text { No KM- } \\
\text { curve }\end{array}$ & $34 \mathrm{mo}$ & $31 \mathrm{mo}$ & $\begin{array}{l}\text { Toxic } \\
\text { death (in- } \\
\text { terim } \\
\text { data } \$) \text { : } \\
7 \% \\
\text { "Early } \\
\text { mor- } \\
\text { tality" N= } \\
8(7 \%)\end{array}$ & $\begin{array}{l}\text { Toxic } \\
\text { death (in- } \\
\text { terim } \\
\text { data } \$ \text { ): } \\
9 \% \\
\text { "Early } \\
\text { mor- } \\
\text { tality" N= } \\
13(12 \%) \\
;\end{array}$ & $\begin{array}{l}\text { Final OS } \\
\text { survival } \\
\text { propor- } \\
\text { tions sim- } \\
\text { ilar }\end{array}$ \\
\hline Bologna96 & $\begin{array}{l}70 \\
\text { mo (me- } \\
\text { dian for } \\
\text { survivors) }\end{array}$ & $\begin{array}{l}\text { no KM- } \\
\text { curve } \\
\text { (inconsis- } \\
\text { tent me- } \\
\text { dian OS } \\
\text { and } \\
7 \text { year OS } \\
\text { (TASCT } \\
43 \quad \text { vs } \\
\text { SASCT } \\
46 \% \text { ) in- } \\
\text { dicate } \\
\text { crossing } \\
\text { curves) }\end{array}$ & $71 \mathrm{mo}$ & $65 \mathrm{mo}$ & $\begin{array}{l}\text { TASCT } \\
\text { superior; } \\
\text { sep- } \\
\text { aration of } \\
\text { curves af- } \\
\text { ter } \quad 18 \\
\text { mo; } \\
5 \text { y EFS: } \\
29 \% \quad \text { vs } \\
17 \%\end{array}$ & $35 \mathrm{mo}^{*}$ & $\begin{array}{l}23 \mathrm{mo}^{*} \\
\mathrm{P}=0.001\end{array}$ & $\begin{array}{l}\text { Trans- } \\
\text { planta- } \\
\text { tion- } \\
\text { related } \\
\text { deaths } \\
\text { Table } 5 \\
4 \%\end{array}$ & $\begin{array}{l}\text { Trans- } \\
\text { planta- } \\
\text { tion- } \\
\text { related } \\
\text { deaths } \\
\text { Table } 5 \\
3 \%\end{array}$ & $\begin{array}{l}\text { Compli- } \\
\text { ance with } \\
\text { second } \\
\text { ASCT: } \\
65 \%\end{array}$ \\
\hline $\begin{array}{l}\text { GMMG- } \\
\text { HD2 }\end{array}$ & $\begin{array}{l}\text { Unclear } \\
2003: \\
36 \mathrm{mo} \\
2005: \\
24 \mathrm{mo} \\
2007 \text { (fi- } \\
\text { nal): NR }\end{array}$ & $\begin{array}{l}\text { ITT: su- } \\
\text { perim- } \\
\text { posable } \\
\text { curves } \\
\text { (multi- } \\
\text { ple cross- } \\
\text { ings); } \\
\text { PP: } \\
\text { SASCT } \\
\text { slightly } \\
\text { superior }\end{array}$ & ca. $77 \mathrm{mo}$ & ca. $72 \mathrm{mo}$ & $\begin{array}{l}\text { ITT: } \\
\text { TASCT } \\
\text { tran- } \\
\text { siently su- } \\
\text { perior; } \\
\text { crossing } \\
\text { of curves } \\
\text { at } 38 \text { mo; } \\
\text { PP: simi- } \\
\text { lar to ITT }\end{array}$ & ca. $29 \mathrm{mo}$ & ca. $25 \mathrm{mo}$ & $\begin{array}{l}\text { So-called } \\
\text { TRM } \\
\text { Table } 5 \\
\text { 1st 2\% } \\
\text { 2nd 3\% } \\
\text { (popu- } \\
\text { lation un- } \\
\text { clear) }\end{array}$ & $\begin{array}{l}\text { So-called } \\
\text { TRM } \\
\text { Table } 5 \\
2 \% \\
\text { (popu- } \\
\text { lation un- } \\
\text { clear) }\end{array}$ & $\begin{array}{l}\text { Compli- } \\
\text { ance with } \\
\text { second } \\
\text { ASCT: } \\
52 \% \text { of } \\
\text { evaluable } \\
\text { patients }\end{array}$ \\
\hline
\end{tabular}

First-line tandem high-dose chemotherapy and autologous stem cell transplantation versus single high-dose chemotherapy and 


\begin{tabular}{|c|c|c|c|c|c|c|c|c|c|c|}
\hline DSMM-I & $\begin{array}{l}\text { ca. } \quad 48 \\
\text { months } \\
\text { (reported } \\
\text { as median } \\
\text { follow- } \\
\text { up; } \\
\text { according } \\
\text { to KM: } \\
\text { total fol- } \\
\text { low-up) }\end{array}$ & $\begin{array}{l}\text { TASCT } \\
\text { initially } \\
\text { superior; } \\
\text { crossing } \\
\text { of KM } \\
\text { curves at } \\
36 \mathrm{mo} \text {; } \\
4 \mathrm{yr} \text { OS } \\
72 \% \text { in } \\
\text { both arms }\end{array}$ & $\begin{array}{l}\text { Not } \\
\text { reached }\end{array}$ & $\begin{array}{l}\text { Not } \\
\text { reached }\end{array}$ & $\begin{array}{l}\text { TASCT } \\
\text { initially } \\
\text { superior; } \\
\text { crossing } \\
\text { of KM } \\
\text { curves at } \\
22 \text { mo }\end{array}$ & $36,4 \mathrm{mo}$ & $\begin{array}{l}\text { ca. } 43.4 \\
\text { mo }\end{array}$ & $\begin{array}{l}\text { So-called } \\
\text { TRM } \\
\text { (exclud- } \\
\text { ing in- } \\
\text { duction) } \\
\text { Table } 5 \\
4 \% \\
\text { (popula- } \\
\text { tion?); } \\
\text { (OS at } \\
100 \% \text { for } \\
400 \text { d ac- } \\
\text { cording } \\
\text { to KM- } \\
\text { curve) }\end{array}$ & $\begin{array}{l}\text { So-called } \\
\text { TRM } \\
\text { (exclud- } \\
\text { ing in- } \\
\text { duction) } \\
\text { Table } 5 \\
3 \% \\
\text { (popula- } \\
\text { tion?) }\end{array}$ & $\begin{array}{l}\text { high pro- } \\
\text { portion } \\
\text { of cross- } \\
\text { over; }\end{array}$ \\
\hline
\end{tabular}

* statistically significant difference; ca. = read from Kaplan-Meier plots

$\S$ interim data with $85 \%$ of enrolled patients

\section{A P P E N D I CES}

\section{Appendix I. MEDLINE search strategy}

\#7 Search myelom*[Text Word]\#8 Search kahler*[Text Word]

\#9 Search plasmacytom*[Text Word]

\#10 Search plasmocytom*[Text Word]

\#12 Search "stem cell transplantation”[MeSH Major Topic]

\#13 Search "transplantation, autologous"[MeSH Major Topic]

\#14 Search “transplantation, homologous”[MeSH Major Topic]

\#16 Search transplant*[Text Word]

\#17 Search graft*[Text Word]

\#19 Search autolog*[Text Word]

\#23 Search autograft*[Text Word]

\#24 Search auto-graft* [Text Word]

\#25 Search auto-transplant*[Text Word]

\#26 Search autotransplant*[Text Word]

\#27 Search asct*[Text Word]

\#28 Search abmt*[Text Word]

\#39 Search "multiple myeloma”[MeSH Major Topic]

\#40 Search \#7 or \#8 or \#9 or \#10 or \#39

\#50 Search (\#12 or \#16 OR \#17) AND \#19

\#52 Search \#13 OR \#14 OR \#23 OR \#24 OR \#25 OR \#26 OR \#27 OR \#28 OR \#50

\#53 Search \#40 and \#52

\#55 Search (Therapy/Broad[filter] OR EBMT[All Fields] OR IBMTR[All Fields] OR

First-line tandem high-dose chemotherapy and autologous stem cell transplantation versus single high-dose chemotherapy and 
(registry[tw] OR register[tw]) OR "center experience" [tw] OR "centre experience")

AND ("humans" [MeSH Terms] AND (English[lang] OR French[lang] OR

German[lang]) AND (“1995”[PDAT] : “2010”[PDAT]))

\#56 Search \#53 and \#55

\section{Appendix 2. CENTRAL search strategy}

$1 \mathrm{MeSH}$ descriptor MULTIPLE MYELOMA explode all trees

2 (myelom* or myeloom* or mielom*).tw,kf,ot.

3 myelomatos*.tw,kf,ot.

4 (kahler or kahler's).tw,kf,ot.

5 (plasm* $^{*}$ cytom* or plasmozytom*).tw,kf,ot.

$6 \# 1$ or $\# 2$ or \#3 or \#4 or \#5

$7 \mathrm{MeSH}$ descriptor STEM CELL TRANSPLANTATION

explode all trees

$8 \mathrm{MeSH}$ descriptor TRANSPLANTATION, AUTOLOGOUS

explode all trees

$9 \mathrm{MeSH}$ descriptor TRANSPLANTATION, HOMOLOGOUS

explode all trees

10 \#7 or \#8 or \#9

11 (transplant* or graft*).tw,kf,ot.

12 autolog*.tw,kf,ot.

$13 \# 11$ and \#12

14 (autograft* or auto-graft*).tw,sh,ot.

15 (homograft* or homo-graft*).tw,sh,ot.

16 (autotransplant* or auto-transplant*).tw,sh,ot.

17 ((tandem* ${ }^{*}$ or double*) near/3 transplant*).tw,kf,ot.

18 (asct or abmt).tw,kf,ot.

$19 \# 14$ or \#15 or \#16 or \#17 or \#18

$20 \# 10$ or $\# 13$ or $\# 19$

$21 \# 6$ and \#20

\section{H I S T O R Y}

Protocol first published: Issue 1, 2004

Review first published: Issue 10, 2012

\begin{tabular}{l|l|l}
\hline Date & Event & Description \\
\hline 26 May 2008 & Amended & Converted to new review format. \\
\hline
\end{tabular}

First-line tandem high-dose chemotherapy and autologous stem cell transplantation versus single high-dose chemotherapy and 


\section{CONTRIBUTIONSOFAUTHORS}

NF: updating protocol (based on earlier version), searching, eligibility screening, data extraction and quality assessment, content input, interpretation of findings

AG: drafting of first version of the protocol, searching, eligibility screening

PB: interpretation of findings and providing a clinical perspective

JB: methodological expert

AE: providing a clinical perspective

RS: searching, eligibility screening, data checking and quality assessment, interpretation of findings, providing a clinical perspective

\section{DECLARATIONS OF INTEREST}

No interests to declare.

The views and opinions expressed in the systematic review are those of the individual authors and should not be attributed to the institutions where they are employed.

\section{SOURCES OF SUPPORT}

\section{Internal sources}

- No sources of support supplied

\section{External sources}

- New Source of support, Not specified.

\section{DIFFER NCESBETWE N PROTOCOLANDRE I EW}

While performing the review, we had to restrict our search to publications in English, French and German and had to exclude the database EMBASE due to budgetary restrictions.

Initially, it was planned to perform a statistical meta-analysis for the included studies. In view of notable clinical heterogeneity and several methodological issues, the presented results are limited to a narrative systematic review. Furthermore, response and time-toprogression were not analysed. In addition to newly diagnosed patients, studies with previously treated patients were acceptable as long as the treatment was conventional and of limited duration (up to six months). Instead of limiting our systematic search to RCTs as planned in the protocol, we also searched for observational studies with contemporary control groups.

The outcome transplantation-related mortality was only vaguely defined in the majority of trials. Instead of including only trials reporting transplantation mortality (as initially planned), we extracted results where all kind of definitions for early mortality were used.

Fewer authors contributed to the finalisation of the review compared to the protocol.

First-line tandem high-dose chemotherapy and autologous stem cell transplantation versus single high-dose chemotherapy and 


\section{NOTES}

None

First-line tandem high-dose chemotherapy and autologous stem cell transplantation versus single high-dose chemotherapy and autologous stem cell transplantation in multiple myeloma, a systematic review of controlled studies (Review)

Copyright (C) 2012 The Cochrane Collaboration. Published by John Wiley \& Sons, Ltd. 